\title{
THE EGGS AND LARVAE OF THE BRITISH PROSOBRANCHS WITH SPECIAL REFERENCE TO THOSE LIVING IN THE PLANKTON
}

\author{
By Marie V. Lebour, D.Sc. \\ Naturalist at the Plymouth Laboratory
}

(Text-figs. I-4)

\section{CONTENTS}

\begin{tabular}{|c|c|c|c|c|c|c|c|c|c|c|c|}
\hline & & & & & PAGE & & & & & & PAGE \\
\hline INTRODUCTION & . & . & . & . & 105 & MESOGASTROPODA & (contd.) & & & & \\
\hline ARCHAEOGASTROI & PODA & & . & . & IIO & Triphoridae &.$\quad$. & . & . & . & 138 \\
\hline Haliotidae & . & . & . & . & II 7 & Epitoniidae & . & . & . & . & I39 \\
\hline Fissurellidae & . & . & . & . & II 7 & Ianthinidae & . & . & & . & I39 \\
\hline Patellidae. & . & . & . & . & II 8 & Eulimidae . & . & . & . & . & 140 \\
\hline Lottiidae . & . & . & . & . & II9 & Styliferidae & . & . & . & . & I40 \\
\hline Trochidae & . & . & . & . & II & Pyramidellidae & . & . & . & . & I4I \\
\hline Turbinidae & . & . & $\cdot$ & . & I 24 & Trichotropidae & . & . & . & . & I 42 \\
\hline MESOGASTROPOD & & . & . & . & I 24 & Capulidae. & . & . & & . & I43 \\
\hline Lacunidae & . & . & . & ${ }^{\prime}$ & I24 & Calyptraeidae & . & . & . & . & I44 \\
\hline Hydrobiidae & . & . & . & . & I 28 & Aporrhaiidae & . & . & . & . & I 44 \\
\hline Rissoidae. & : & . & . & . & I29 & Naticidae & . & . & . & . & I 45 \\
\hline Tornidae . & . & . & . & 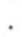 & I34 & Lamellariidae & . & . & . & . & I47 \\
\hline Skeneopsidae & . & . & . & . & I35 & Cypraeidae & . & . & . & $\cdot$ & I49 \\
\hline Omalogyridae & & . & . & . & I35 & STENOGLOSSA & . & . & . & . & 152 \\
\hline Rissoellidae & . & . & . & . & I 35 & Muricidae. & . & . & . & . & I52 \\
\hline Turritellidae & . & . & 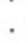 & . & 136 & Buccinidae & . & . & . & . & I54 \\
\hline Caecidae & 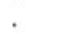 & . & . & . & I36 & Nassariidae & . & & & . & I57 \\
\hline Cerithiidae & & . & . & ${ }^{\circ}$ & I 37 & Turridae . & . & & & . & I58 \\
\hline Cerithiopsidae & & . & $\cdot$ & ${ }^{\circ}$ & I37 & REFERENCES . & . & & & . & I62 \\
\hline
\end{tabular}

\section{INTRODUCTION}

Molluscs are very important members of our marine fauna, and, since many of them are planktonic in their early stages, they contribute largely to the number of organisms available as food for plankton-eating animals. The present work includes the prosobranchs only, particularly those from Plymouth which have been specially studied during the last few years. Several papers have already been published dealing with the Plymouth species (Lebour, I93I-6), and these are referred to in due course. The present paper brings together the above work and that of others and summarizes our knowledge of the larval prosobranchs of Britain, with a description of the eggs. Naturally there are still many gaps, but it is hoped that these may be filled in time. A preliminary 
paper on the subject has already appeared (Lebour, I933f). Closely related foreign species are referred to for comparison with our British forms. Original notes on certain species and information on the echinospira larva of Capulus ungaricus are given here for the first time. Figures of typical eggs and larvae are given.

Early work on the embryology of marine prosobranchs deals almost entirely with the development of the egg up to the time of hatching, and only in a few species, and these chiefly the primitive forms, is the larva described in the free-swimming stage. Very little was known about late veligers of the majority of the gastropods whose larvae remained long in the plankton. Lund's (1834) early classification of the various spawn cases is very interesting, although now out of date. Lamy (1928) gives a good account of the spawn of prosobranchs in general. Lovén (I839, I844) and Krohn (I853, I855, I857) were some of the earliest workers to note prosobranch veligers in the plankton and to attribute them to their proper genera, and several planktonic larvae were described by others who believed them to be adult forms (Sinusigera, Macgillivrayia, etc.), although Macdonald (1855, I859), Adams (I857, I86I) and Craven (1877, I883) were already beginning to see their real significance. Fischer (I884) gives an account of these. These names are still sometimes used to denote larval forms whose adults are not known (Simroth, I895; Vayssière, I92330). Simroth (1896, I907, I9II), Fischer (I884), Odhner (I9I4), Pelseneer (I894, I906, I9II, I926) and recently Vestergaard (1935) all note various planktonic veligers, but of few if any were the complete life histories known. The recent exceedingly interesting work of Thorson (1935) on East Greenland prosobranchs shows that none in those regions has planktonic larvae but all hatch out in the crawling stage. Jeffreys (1863-69) notes the eggs and larvae of the British forms whenever possible. The very few planktonic larvae recorded by Simroth (I9II) in his Gastropoda in Nordisches Plankton show the small number of free-swimming veligers known at that time from northern regions. Lo Bianco (1888-9) gives valuable notes on the breeding season and spawn of certain prosobranchs at Naples. Simroth (I896I907) summarizes our knowledge of eggs and larvae with special reference to general embryology. General accounts are given by Pelseneer (1894, I906), Fischer (I887) and MacBride (I9I4).

The study of the prosobranch gastropods at Plymouth indicates that a very large number live for a certain time as larvae in the plankton, including several species which live high up between tide marks. Those which remain only a few hours or days as veligers may yet be very important on account of their numbers or the long range of their breeding season. A few are of no importance at all from the point of view of plankton food, for they hatch out in the crawling stage, or, very rarely, are viviparous. As a rule the larvae with the most elaborate velum of four to six lobes (Fig. $4 c, g, h$ ) are those which are found farthest out to sea and remain longest in the plankton. These generally have a shell of several whorls before they settle down and lose the larval features. 
Examples are Nassarius incrassatus ${ }^{\star}$ and Trivia arctica, which both have a much larger velum with longer lobes than their close relatives Nassarius reticulatus and Trivia monacha to be found in shallower waters. Small forms may, however, have many whorls and an insignificant velum, and occur in even deeper water, remaining long in the plankton. Examples of such species are Balcis alba, Triphora perversa and Cerithiopsis spp., and some Turrids. These may, however, also be found in shallower waters.

To begin with the highest position on the shore, there are molluscs which usually live above high-water mark. Of these the classical instance is Littorina saxatilis $(=L$. rudis) which may be found beyond the highest tide limit and also between tide marks, and is viviparous. L. neritoides, formerly also regarded as viviparous, is now known to have planktonic egg capsules and to hatch out as a free-swimming veliger. This species has a restricted range and is generally to be found well above high-water mark, often with L . saxatilis. Monodonta lineata, one of the Trochidae, also living near high-water mark, sometimes with Littorina neritoides, sheds its eggs singly into the sea and so also does Patella, the common limpet. In both species a free-swimming larva results which remains a very short time in the plankton. The common species of Gibbula, G. cinerarius and G. umbilicalis have eggs and young similar to Monodonta. On the other hand, many of the Rissoids, living high up in the rock pools between tide marks, lay small capsules of eggs which hatch as veligers with a long free-swimming life. Cingula cingillus is a notable exception, for, living under stones sometimes above high-water mark, it lays egg capsules from which the young emerge in the crawling stage-and so also does Cingula (Anoba) semicostata, which lives rather lower down and is sometimes dredged below the low-water level. The position between tide marks or otherwise is not always the important factor in determining whether there is a free-swimming larval stage or a crawling young, for one Rissoid may live very high up and have a planktonic veliger, whilst another, closely related, may live much lower down and have no free-swimming stage at all. Rissoa parva, with an extensive range between tide marks, has a veliger which remains long in the plankton, whilst its close relative Barleeia unifasciata, which may be actually living with it at extreme low-water mark, has no free-swimming stage at all. Littorina littoralis ( $=$ L. obtusata) living on Fucus between tide marks has no freeswimming stage, the young hatching as miniatures of the parent; but Littorina littorea, often living quite near it on the rocks, has planktonic egg capsules with young hatching as veligers. Again, Lacuna vincta and L. pallidula both lay gelatinous masses of eggs on weeds between tide marks, but the first has free-swimming larvae, while the latter hatches in the crawling stage. Many of the Stenoglossa, either living between tide marks or always under water, hatch in the crawling stage (Buccinum undatum, Nucella lapillus, etc.),

* The nomenclature is according to Winckworth's list (1932). When this differs from the Plymouth Marine Fauna (Marine Biological Association, I93I) the equivalent names are placed in brackets. 
but may have free-swimming larvae, for example, all the British Turrids whose larvae are known. From these few instances one sees that on British coasts it is usually impossible to deduce from the habitat of the mollusc what sort of larva it will have. Each species must be studied separately and its life history known before we can be sure which is important in the plankton and which is not.

The prosobranchiate gastropods are divided into three orders, the Archaeogastropoda, the Mesogastropoda and the Stenoglossa. Of these the Archaeogastropoda are clearly differentiated from the other two in the larval form, the young being of a much more primitive character. The embryology of this order has been investigated much more thoroughly than that of the other two, and a fair amount is known of the eggs and young and their development. There is frequently a free-swimming trochophore stage, and the velum is a flat organ with a more or less circular outline. The nourishing material is contained in the egg itself as in Patella and Patina, or there is a thin layer round the egg membrane as in Gibbula and Monodonta. In consequence the nourishment available is small and the planktonic stage is short; nevertheless, in the common shore species, Patella, Gibbula, etc., the larvae are so numerous that they are very important members of the plankton. Diodora, Calliostoma and Cantharidus hatch in the crawling stage.

In the Mesogastropoda and Stenoglossa the eggs are not shed singly into the water, but, unless the animal is viviparous, they are covered with a more or less thick protective sheath or capsule. The larva is nourished inside this until it escapes either as a well-formed veliger with a bilobed or four-lobed velum or as a crawling form resembling its parent. Usually the more safely the eggs are protected the fewer there are in the sheath or capsule.

The eggs and simple free-swimming early larvae of the Archaeogastropoda before the shell is formed are all very much alike, but there is a great variety both in the spawn and larva of the other two orders.

\section{THe EGg AND ITS COVERING}

(Figs. $\mathrm{I} a, b, c, g, k, l, m$ )

When newly extruded from the ovary the egg $(E)$ is provided with a thin membrane-the egg membrane $(M)$. A thin gelatinous layer sometimes covers this, as in Patella (Fig. I $c, G$ ) and Patina, which swells up in the water. The membrane and gelatinous layer very soon disappear in Patella and its relatives and development of the egg proceeds without any covering. In most of the Archaeogastropoda, however, the egg membrane is covered by an albuminous layer $(A)$, more or less thin, and an outer coat, the egg covering $(C)$, a gelatinous sheath which swells up in the water frequently covering the whole $(G)$. The egg covering is called by some authors the egg capsule, the latter term being here reserved for the hardened outer sheath which is outside the covering and 

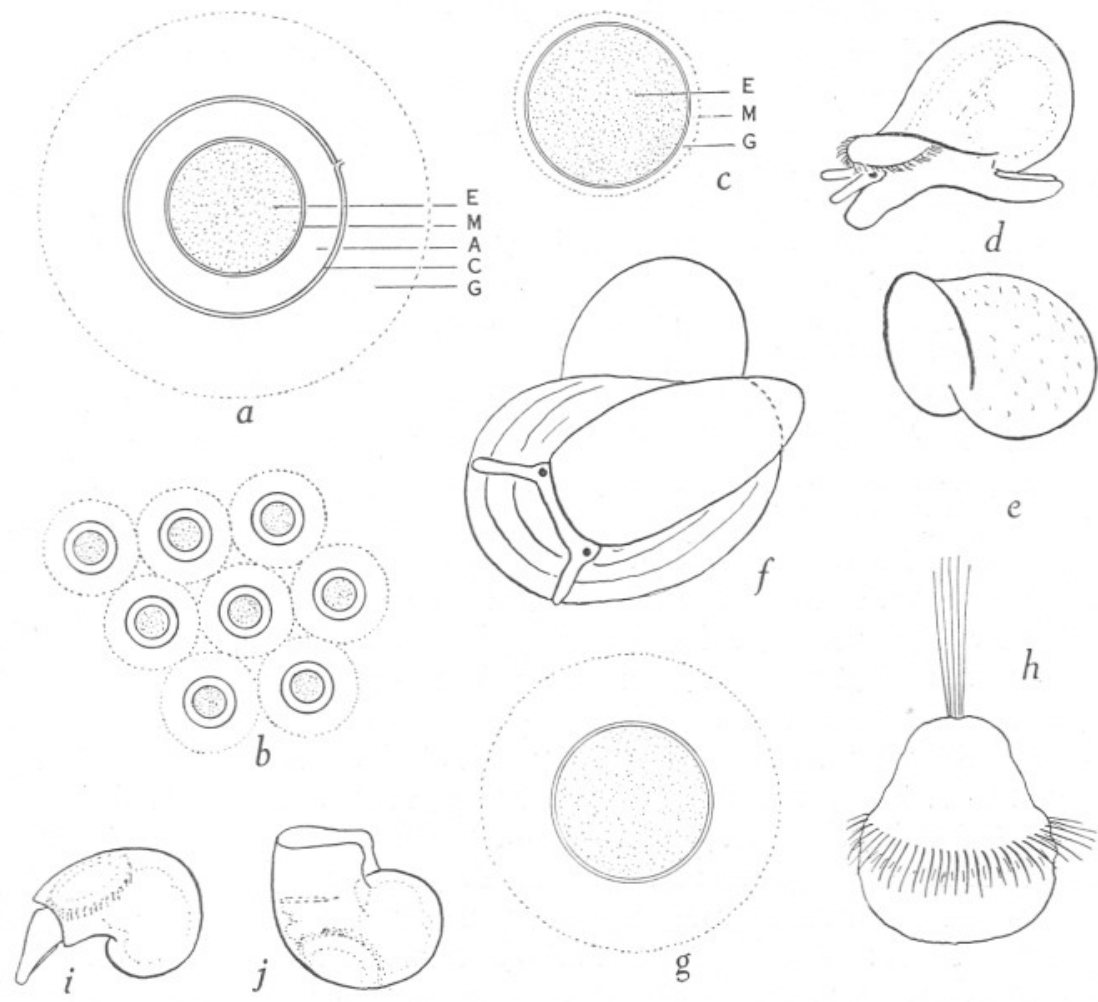

e

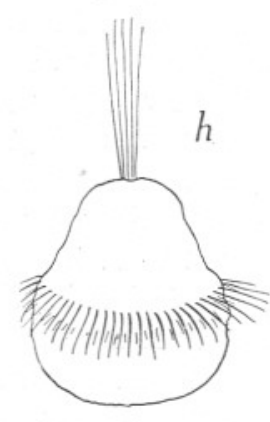

g
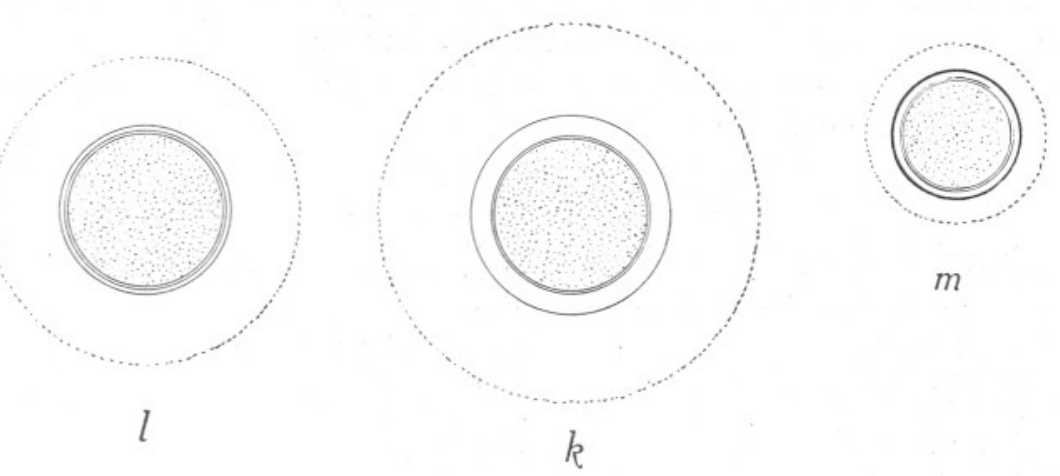

$m$

Fig. I. $a, b$ : Diodora apertura. $a$, individual egg, $0.48 \mathrm{~mm}$. across gelatinous layer; $b$, eggs from egg mass. $c-f$ : Patella vulgata. $c$, egg, newly laid, $0.16 \mathrm{~mm}$. across; $d$, crawling larva with velum, shell $0.2 \mathrm{~mm}$. across; $e$, shell of same; $f$, young shell from rock crevice, $0.38 \mathrm{~mm}$. across. g- $j$ : Patina pellucida. $g$, egg, newly laid, $0.32 \mathrm{~mm}$. across; $h$, trochopore larva $0.2 \mathrm{~mm}$. high; $i$ and $j$, veligers, with shells $0.16 \mathrm{~mm}$. and $0.18 \mathrm{~mm}$. across. $k$ : Monodonta lineata, egg, $0.48 \mathrm{~mm}$. across. $l$ : Gibbula umbilicalis, egg, $0.32 \mathrm{~mm}$. across. $m$ : Tricolia pullus, egg, 0.14 mm. across. 
occurs mainly in the higher prosobranchs. Single eggs with membrane, albuminous layer, egg covering and gelatinous sheath occur in Gibbula, Monodonta and Tricolia (Fig. I $k, l, m$ ). In Diodora (Fig. I $a, b$ ) the gelatinous sheath of each egg joins its neighbour, so that a layer of eggs, one cell thick, is laid on a substratum. This leads to the gelatinous ribbon of many of the Trochidae-Calliostoma and Cantharidus - in which a further gelatinous substance keeps the mass of eggs together (Fig. 2a). This gelatinous substance may form a pellicle on the outer surface, making the egg mass or ribbon more or less firm. So far as is at present known no more elaborate form of spawn occurs in the Archaeogastropoda.

In the Mesogastropoda and Stenoglossa the outer covering may be soft or hard and frequently forms a capsule of very definite shape-lens-shaped, flask-shaped, vase-shaped, etc. The various layers covering the eggs are formed from special glands, different according to the kind of spawn. These are well described for Littorina by Linke (1933a) and for Lacuna by Hertling (I928). Pelseneer (I9IO, I926) has also described some of these glands and gives a further list of authorities. In the Mesogastropoda and Stenoglossa the egg membrane is often very difficult to see, but is probably always present at some time. Frequently the egg is without a perceptible membrane and floats in a nourishing fluid contained in the capsule (Rissoa, Nassarius) or it may be covered with an albuminous layer and egg covering and then float in the capsule (Littorina littorea). In Littorina littorea the outer capsule contains a fluid in which float one to five eggs, each with an egg membrane, an albuminous layer and an egg covering, whilst in Rissoa the egg or eggs, covered by a very thin membrane, float directly in the fluid contained in the capsule.

In the following lists the various kinds of eggs and larvae are roughly grouped together, so far as they are known. Under the Archaeogastropoda and Stenoglossa both are treated together, but they are dealt with separately under the Mesogastropoda.

\section{ARCHAEOGASTROPODA}

Eggs set free singly in the plankton, veliger stage short. Larvae of some importance in the plankton (Fig. I $c, g, k, l, m$ ):

Haliotis tuberculata

Patella vulgata (and allied species)

Patina pellucida

Patelloida virginea

Gibbula magus

Eggs laid in gelatinous masses or ribbons, young hatched in crawling stage. Larvae of no importance in the plankton (Figs. $1 a, b ; 2 a$ ):

Diodora apertura

Gibbula tumida

Margarites helicinus

Calliostoma zizyphinum
Gibbula cineraria

G. umbilicalis

Monodonta lineata

Tricolia pullus
Calliostoma papillosum

Cantharidus striatus

C. exasperatus

Skenea serpuloides 


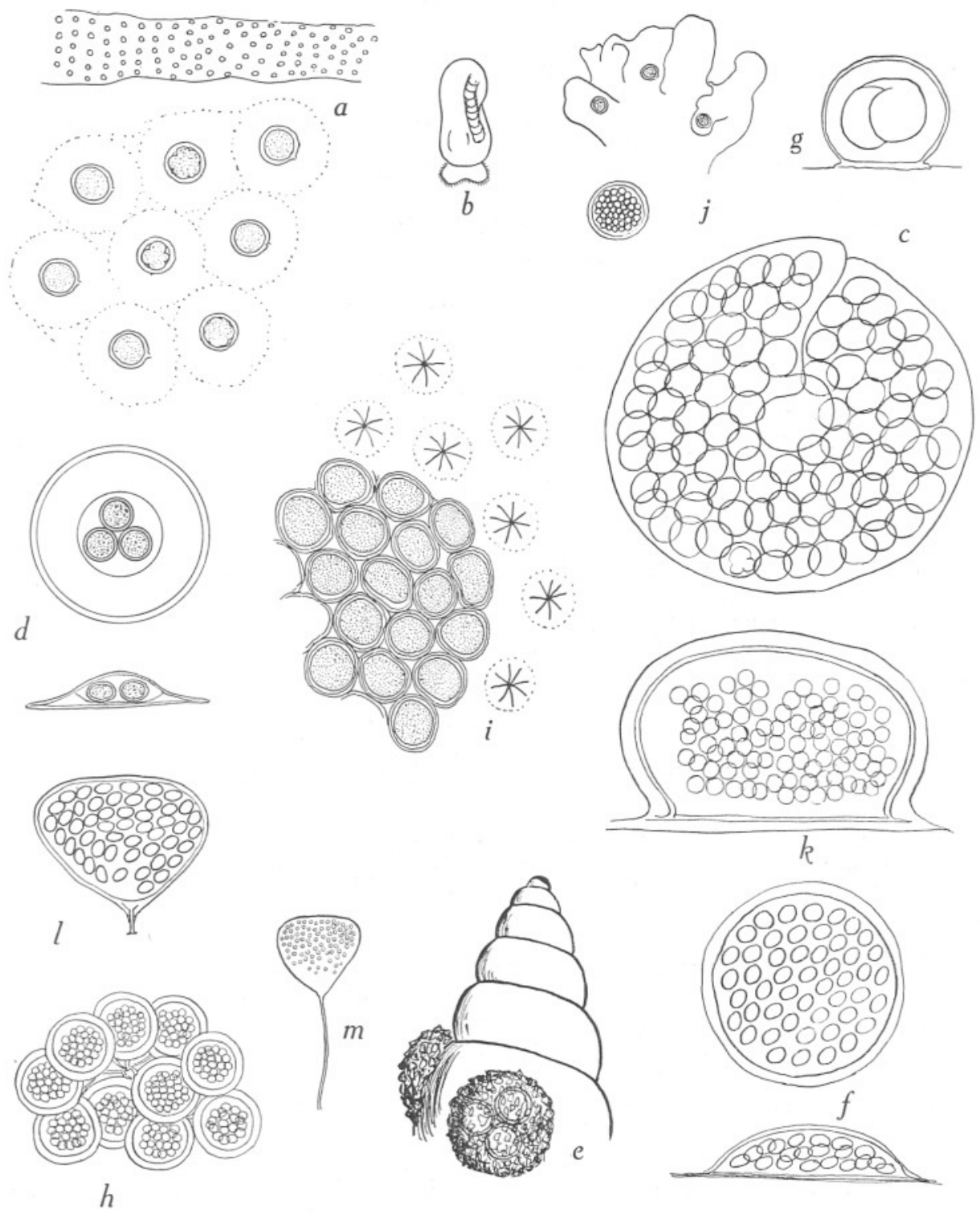

Fig. 2. a: Calliostoma zizyphinum, eggs $0.32-0.4 \mathrm{~mm}$.; portion of egg ribbon and a part more highly magnified. $b$ : Omalogyra atomus, with eggs inside shell. $c$ : Lacuna vincta, egg mass, $3 \mathrm{~mm}$. across. d: Littorina littorea, planktonic egg capsule, $0.96 \mathrm{~mm}$. across. $e$ : Hydrobia ulvae, egg capsule laid on neighbour's shell, ca. $0.6 \mathrm{~mm}$. across. $f$ : Rissoa parva, egg capsule, $0.64 \mathrm{~mm}$. across. $g$ : Skeneopsis planorbis, egg capsule, $0.48 \mathrm{~mm}$. across. $h$ : Turritella communis, egg capsules; capsule $0.64 \mathrm{~mm}$. across. $i$ : Simnia patula, egg capsules; capsule $0.13 \mathrm{~mm}$. across. $j$ : Cerithiopsis tubercularis, egg capsules laid in the sponge Hymeniacidon; capsule $0.35 \mathrm{~mm}$. across. $k$ : Balcis alba, egg capsule, $3 \mathrm{~mm}$. across. $l$ : Pelseneeria stylifera, egg capsule, $\mathrm{I} \cdot 2 \mathrm{~mm}$. across. $m$ : Crepidula fornicata, egg capsule, $3.5 \mathrm{~mm}$. across (from mass covered by parent). 


\section{MESOGASTROPODA}

\section{VIVIPAROUS}

Littorina saxatilis

Hydrobia ventrosa (fresh water, near sea)

\section{LAYING EGGS}

Eggs in capsules carried inside shell:

Omalogyra atomus (Fig. 2b)

Eggs in gelatinous masses attached to a substratum:

\section{Littorina littoralis}

Lacuna vincta (Fig. 2c)
Lacuna pallidula

Odostomia eulimoides

Eggs in planktonic capsules:

Littorina littorea (Fig. 2d)

L. neritoides

Several unknown species

Eggs in lens-shaped capsules attached to the substratum containing several eggs:

Hydrobia ulvae (laid on shell of neigh- Rissoa inconspicua

bours) (Fig. 2e)

Cingula semistriata

Alvania punctura

R. parva (Fig. $2 f$ )

R. guerini

Rissoa sarsii

R. membranacea

Chrysallida decussata

Eggs in spherical or oval capsules containing one or two eggs, attached to substratum or on bottom:

Cingula fulgida

C. semicostata

C. cingillus

Barleeia unifasciata
Skeneopsis planorbis (Fig. 2g)

Rissoella diaphana

Aporrhais pespelicani

Eggs on bottom in grape-like clusters:

Turritella communis (Fig. $2 h$ )

Eggs in layers of capsules, one cell thick or one capsule thick, on a substratum:

Triphora perversa Simnia patula (Fig. 2i)

Eggs in nests in sponges:

Cerithiopsis tubercularis (Fig. $2 j$ )

Cerithiopsis barleei

Eggs in attached gelatinous coils:

Bittium reticulatum

Eggs in thick, tough, oval capsules attached to a substratum:

Balcis alba (Fig. 2k)

Eggs in triangular capsules attached to echinoderm:

Pelseneeria stylifera (Fig. $2 l$ ) 
Eggs in capsules covered by parent shell:
Calyptraea chinenis
Capulus ungaricus
Crepidula fornicata (Fig. $2 \mathrm{~m}$ )

Eggs in vase-shaped or circular capsules embedded in compound ascidian: Trivia monacha (Fig. $3 a, b$ ) and (almost Lamellaria perspicua certainly) $T$. arctica

Eggs glued in ribbons of sand:
Natica catena
Natica poliana (Fig. 3c)

Eggs in chains of triangular or polygonal capsules covered with sand or mud: Clathrus clathrus (Figs. $3 d, e$ )

\section{LARVAL FORMS}

Young hatched in the crawling stage. Of no importance in the plankton:
Littorina littoralis
Lacuna pallidula
Cingula cingullus
C. fulgida
C. semicostata

Barleeia unifasciata

Skeneopsis planorbis

Rissoella diaphana

Calyptraea chinensis

Larvae hatched as veligers with a short free-swimming stage. Of little importance in the plankton:

Hydrobia ulvae

Turritella communis

Rissoa membranacea

Larvae hatched as veligers with a long larval life. Of importance in the plankton:

Littorina littorea

Rissoa sarsii

R. parva

R. guerini

R. incospicua

Cingula semistriata

Alvania punctura

A. crassa

Tornus subcarinatus

Caecum imperforatum

Odostomia eulimoides

Aporrhais pespelicani

Triphora perversa

Cerithiopsis tubercularis

C. barleei
Bittium reticulatum

Balcis alba

$B$. devians

Pelseneeria stylifera

Lamellaria perspicua

(?) L. latens

Capulus ungaricus

Velutina velutina

Trivia monacha

T. arctica

Erato voluta

Simnia patula

(?) Natica catena

(?) N. poliana echinospira larvae

(Figs. 4a-d) 

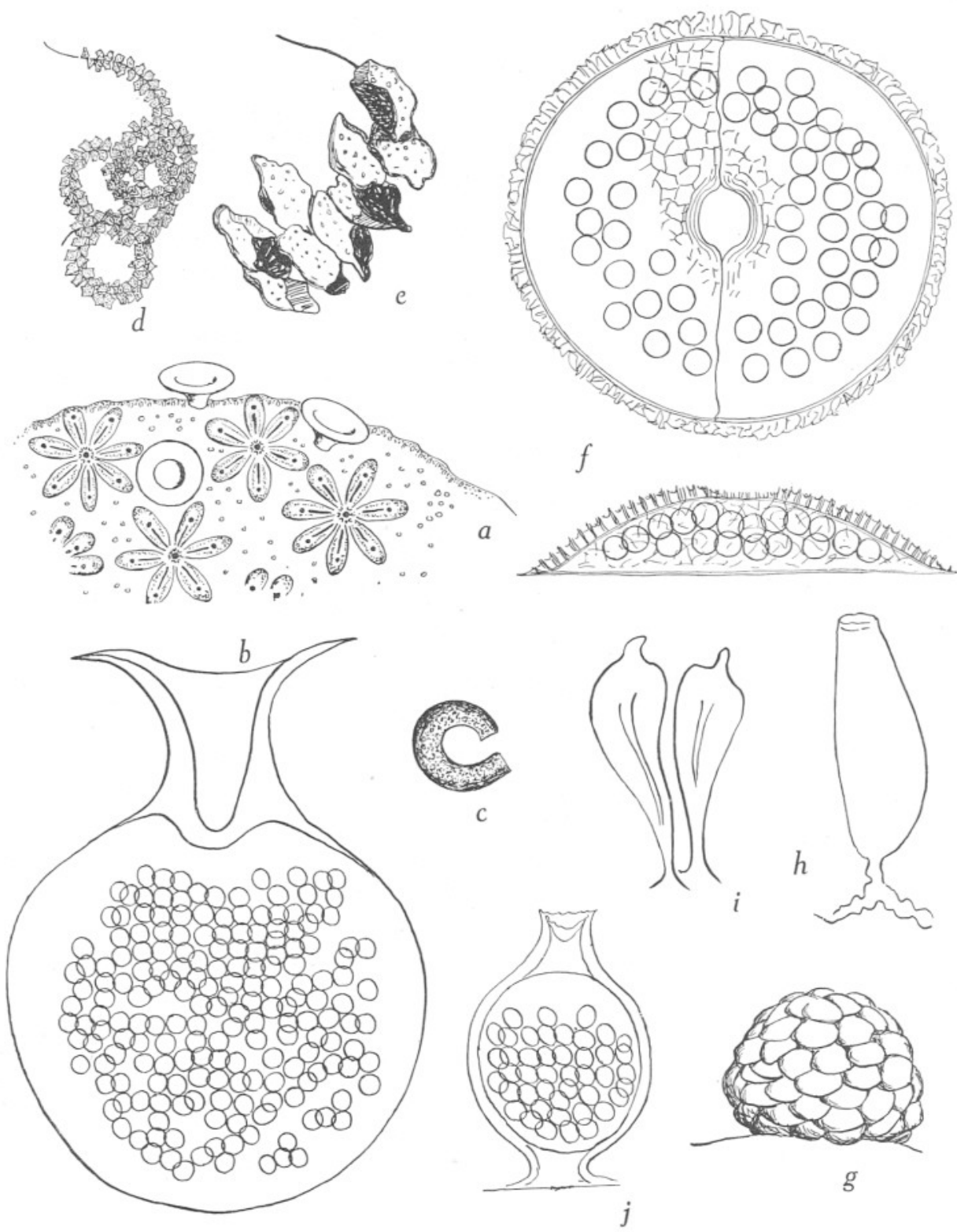

Fig. 3. $a, b$ : Trivia monacha. a, egg capsules in compound ascidian; $b$, a capsule of same isolated, $4.8 \mathrm{~mm}$. high. $c$ : Natica poliana, egg ribbon, ca. $25 \mathrm{~mm}$. across. d, e: Clathrus clathrus. $d$, egg chain, ca. $60 \mathrm{~mm}$. across. $e$, part of same highly magnified, capsule, $c a$. $3 \mathrm{~mm}$. long. $f$ : Philbertia gracilis, egg capsule, $3.4 \mathrm{~mm}$. across. $\mathrm{g}$ : Buccinum undatum, egg mass, ca. $80 \mathrm{~mm}$. across. h: Nucella lapillus, egg capsule, $8 \mathrm{~mm}$. high. $i$ : Ocenebra erinacea, egg capsule, Io mm. high. $j$ : Nassarius incrassatus, egg capsule, $2 \mathrm{~mm}$. high. 

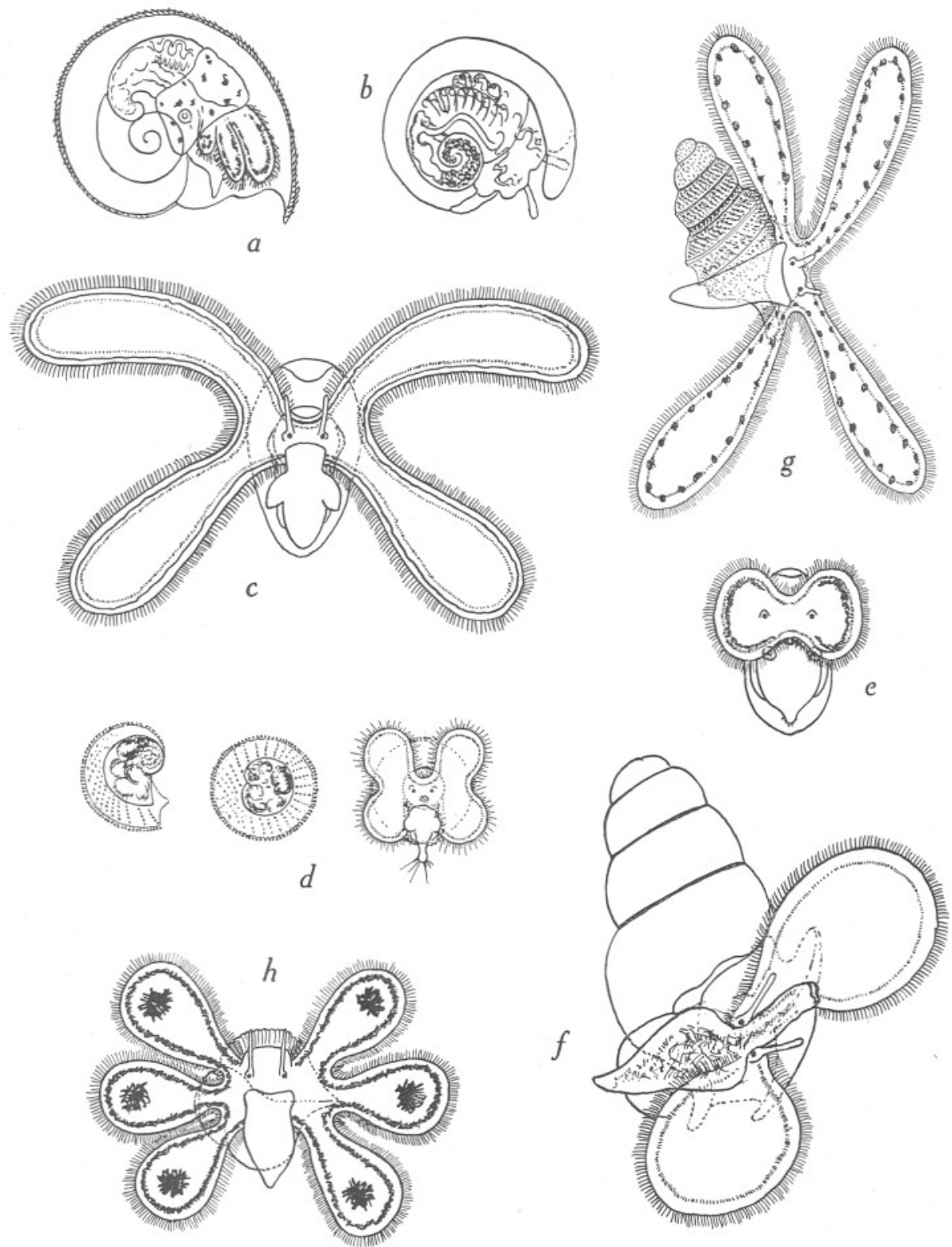

Fig. 4. a: Lamellaria perspicua, echinospira larva, $2 \cdot 24 \mathrm{~mm}$. across (nautiloid form). $b, c$ : Trivia arctica. $b$, echinospira larva, $\mathrm{I} \cdot 44 \mathrm{~mm}$. across (helicoid form). $c$, echinospira larva with velum expanded. $d$ : Capulus ungaricus, echinospira larva. $e$ : Lacuna vincta, newly hatched veliger, velum two-lobed. $f$ : Cerithiopsis tubercularis, late veliger; typical late larva with two-lobed velum. $g$ : Philbertia gracilis, late veliger, typical four-lobed velum. $h$ : Aporrhais pespelicani, late veliger, typical six-lobed velum. 


\section{STENOGLOSSA}

Separate attached lens-shaped capsules containing several eggs. Young hatched in the crawling stage. Of no importance in the plankton:

\section{Trophon muricatus}

Lens-shaped capsules attached to a substratum, containing several eggs. Free-swimming larvae remaining long in the plankton. Of importance in the plankton:
Lora turricula
Mangelia nebula
Philbertia leufroyi
$P$. linearis

Philbertia gracilis (Figs. $3 f ; 4 g$ )

Eggs in more or less lens-shaped capsules, congregated together in lumpy masses, young hatched in crawling stage. Of no importance in the plankton:
Buccinum undatum (Fig. $3 g$ )
Neptunea antiqua

B. humphreysianum

Eggs in solitary capsules, or a few capsules together. Young hatched in crawling stage. Of no importance in the plankton:
Beringius turtoni
Colus gracilis
Volutopsius norwegicus
C. howsei

Colus islandicus

Eggs in vase-shaped capsules, usually several together, attached to a substratum, containing several eggs. Young hatched in crawling stage. Of no importance in the plankton:

Nucella lapillus (Fig. $3 h$ )

Ocenebra erinacea (Fig. $3 i$ )

Urosalpinx cinerea

Eggs in flask-shaped capsules, attached to a substratum, containing several eggs. Free-swimming larvae remaining long in the plankton. Of importance in the plankton:

Nassarius reticulatus

N. incrassatus (Fig. $3 j$ )

Nassarius pygmaeus

\section{Order ARCHAEOGASTROPODA}

(Figs. I $a-m ; 2 a, b$ )

The eggs are laid singly in the water, hatching as trochophore larvae, or in a layer, mass, or ribbon, attached wholly or partly to a substratum and hatching in the crawling stage, the trochophore stage being passed within the egg covering. The velum is circular or (rarely) beginning to be bilobed.

The embryology of this order has been worked out in several genera and species (Boutan, I885, I898, I899; Patten, I886; Robert, I902; Smith, I935; etc.), although less has been done with the later larval stages and post-larval than with the early stages. 


\section{Family HALIOTIDAE}

Haliotis tuberculata L.

\section{Genus Haliotis}

The "Ormer" occurs commonly in the Channel Islands but not on the British mainland. Boutan (I885, I899) describes the eggs, which are set free singly from the holes along the shell. Each egg is a small sphere enveloped in a covering, $0.2 \mathrm{~mm}$. in diameter, surrounded by a little mucus; the yolk is dark green. Wegmann (1884) also describes the egg. Later work on egg and young is by Stephenson (I924) who obtained trochophores I4-I5 hours after fertilization, the larvae hatching from the egg shell (=egg covering) after 44-46 hours. Boutan figures the young larvae and shell, the round velum, the crawling stage and the adult shell beginning to form. The larval shell is at first a single cup, then nautiloid, and finally spiral with about one and a half whorls. The larval operculum disappears at the same time as the velum. At first the shell is without holes, which begin to appear when the animal is less than I mm. long. The free-swimming stage is very short. Crofts (1929) gives a brief review of the eggs and larvae. She found young, $2 \mathrm{~mm}$. long, crawling on stones. ${ }^{\star}$

\section{Family FISSURELLIDAE}

Genus Diodora

Diodora apertura (Montagu) (Figs. I $a, b$ ).

Common in many parts of Britain among rocks near the shore. The eggs are laid in layers one cell thick under stones. Boutan (I885) gives a detailed account of the embryology from the expulsion of the eggs until the fully formed shell stage. The eggs are extruded from the branchial aperture and are apparently fertilized externally. The young hatch in the crawling stage, the velum having almost entirely disappeared. The shell of newly hatched young is spiral, with about one and a half whorls. Later a slit appears at the edge of the older shell, which as the animal and shell grow is gradually closed up and finally reaches the top of the shell.

A male and female were placed in a glass bowl in the Plymouth Laboratory (May 1934), and eggs were laid in an extensive layer, several inches across, on the glass. These agreed with the description of Boutan. The eggs were o. I4 mm. across the thin membrane, yellowish and very opaque, surrounded by an albuminous layer and an egg covering with a micropyle. Round this was a thick gelatinous layer, the whole being about $0.48 \mathrm{~mm}$. across. The gelatinous coverings were pressed together and formed a layer one cell thick, the whole mass measuring about $2 \frac{1}{2}$ in. across. The developing young rotated in the egg covering and grew as far as the ciliated stage, the membrane disappearing. Breeding records from Plymouth are in the months of December, January, March and May.

Lo Bianco (I899) found similar eggs belonging to a related Mediterranean species (Fissurella nubecula L.).

\footnotetext{
$\star$ See note on page 166 .
} 


\section{Family PATELLIDAE}

(Figs. I $c-j$ )

All the members of this family whose breeding is known extrude the eggs singly and fertilization is external. The egg is surrounded by a thin membrane and a gelatinous layer, more or less thick, which swells up in the water. Both disappear soon and development proceeds without any covering. The larva hatches in a few hours as a trochophore with long cilia at the top and a circle of cilia surrounding it. Very soon a simple bowl-shaped shell is developed, and a circular velum, tentacles, eyes and otocysts and an operculum are formed. The shell rapidly becomes slightly spiral with hardly more than one whorl and soon the larva can both swim and crawl. After this it loses the velum and operculum, having only been a few days in the plankton, and settles down, a secondary symmetry appearing both in the shell and the animal.

Patten (I886) describes the embryology of Patella cerulea, and Lo Bianco (I899) reared the same species at Naples from artificial fertilizations. Wilson (I904) worked experimentally on the egg. Boutan (1899) describes briefly the embryology of Patella vulgata. Ainsworth Davis and Fleure (1903) give a short account of its development and so also does Pelseneer (I9II). F. G. W. Smith (1935) describes its development from the egg to the settling stage in detail.

Patina pellucida was found by Smith and also by myself to have eggs and young larvae somewhat similar to Patella, but the larvae are distinguishable. The free-swimming larvae of this family, although staying only a short time in the plankton, are yet of importance on account of their abundance.

\section{Genus Patella}

Patella vulgata L. (Figs. I $c-f$ ).

This is the species most commonly studied in Britain, but the allied $P$. depressa (including $P$. athletica) and $P$. intermedia have been probably confused with it. It is likely, however, that most of the work by British zoologists is on P. vulgata and this is certainly so with Smith's work (1935). This species breeds at Plymouth chiefly during the winter months, but the breeding records may refer to any of the common species referred to above. Orton (I928) found it bred from August to March at Plymouth, the maximum season being in January and February. In March Professor Ohshima reared $P$. vulgata through metamorphosis to young spat from artificial fertilizations (Orton, I928), and MacBride (I9I4) states, probably alluding to unpublished work by the late E. W. Nelson, that it was reared at Plymouth through metamorphosis. This has again been accomplished by Smith (I935).

The newly extruded egg is $0.16 \mathrm{~mm}$. across (Fig. I c). The young developing larva is about $0.16 \mathrm{~mm}$. across and the trochophore about $0.18 \mathrm{~mm}$. across. The 
young shelled larva is $0.2 \mathrm{~mm}$. across. In the late larva, which can both crawl and swim, the shell is $0.22 \mathrm{~mm}$. across. The shell has minute granulations (Fig. I $d, e$ ). The shelled larvae a few days old can be found in numbers in townettings from Plymouth Sound in autumn and winter, especially in January and February, more rarely in late spring and summer. They then settle down and are to be found in barnacle shells and small rock crevices (Fig. If).

\section{Genus Patina}

Patina pellucida (L.) (Figs. I $g-j$ ).

The egg has an egg covering and a thin gelatinous layer rather thicker than in Patella, both of which soon disappear (Fig. I $g$ ). Artificial fertilizations were effected at Plymouth and the larvae reared by Smith (1935), and to early stages by myself. The larva is like Patella, at first a trochophore (Fig. I $h$ ), then with velum and shell. The shells differ from those of Patella in being smaller, smooth and more symmetrical at the outer lip, the margin overlapping at both sides (Figs. I $i, j$ ). The egg is $0.32 \mathrm{~mm}$. across the gelatinous covering; the newly hatched larva $0.2 \mathrm{~mm}$. high; the shell of the late larva $0.16-0.18 \mathrm{~mm}$. across. The species probably breeds at Plymouth throughout the year; the shelled larvae are to be found in the plankton in almost any month and sometimes occur in numbers.

\section{Family LOTTIIDAE \\ Genus Patelloida \\ Subgenus Collisella}

Patelloida tessullata (Müller).

This species lays its eggs embedded in a layer of very thin mucus in which they lie one layer deep at regular distances; the eggs are not shed singly into the water. A trochophore larvae is developed very rapidly (Willcox, 1905).

\section{Subgenus Tectura}

Patelloida virginea (Müller).

Boutan (I898, I899) has described the development as very similar to Patella.

In the closely related Acmaea rubella, Thorson(I935) has shown the existence of viviparity.

\section{Family TROCHIDAE}

(Figs. $\mathrm{I} k, l, m ; 2 a, b$ )

The members of this family, so far as is known, either shed their eggs singly into the sea, like Patella, or they deposit them in gelatinous masses or ribbons attached partly or wholly to some substratum. Robert (I902) has described the eggs and embryology of several British species and some others in his classical 
monograph. This work gives us the most important information which we possess on the eggs and young of the family. Gersch (1936) describes the spawn of some of the species in his detailed account of the genital organs. Moorhouse (1932) states that the large Trochus niloticus, economically important in Australian regions, sends out its eggs separately into the sea where they float in the surface layers. He describes the newly extruded egg as spherical with a diameter ("chorion" included) of $0.3 \mathrm{~mm}$., the egg proper being 0.17 $0.25 \mathrm{~mm}$. across. This kind of egg is typical of certain members of the family, notably various species of Gibbula and Monodonta lineata.

The egg (Figs. I $k, l, m$ ), covered by a thin membrane, lies in an egg covering with a more or less thick albuminous layer between. A micropyle is usually to be seen in the egg covering. Outside the covering is a gelatinous layer which swells up in the water. The single eggs float separately in their spheres of jelly. In most of those species which lay masses or ribbons of eggs the gelatinous spheres are embedded in a further coating of a glutinous nature, which fixes the eggs together and serves as an attachment to some substratum (Fig. 2a). They have thus gone a step farther than the Fissurellidae.

When the eggs are laid singly the young are hatched in an early trochophore stage, not unlike that of Patella; but the membrane, albuminous layer and egg covering with the gelatinous sheath are retained for some time and the larva can be seen revolving inside its coverings. Later, after hatching, a shell and round velum are formed. The larva remains only a few days in the plankton. Before settling down the shell is already spiral.

In those species which lay their eggs in masses or ribbons the larvae, so far as is known, are hatched in the crawling stage, having passed the veliger stage within the egg covering. Known species of Calliostoma have the ribbon attached at one end or for part or the whole of one surface, in those of Cantharidus the eggs are in smaller masses attached by the whole of one surface. The eggs may be arranged irregularly or in a chaplet. Here again, although only remaining for a short time in the plankton, those larvae which are free-swimming are of importance on account of their abundance.

Winckworth (1932) places the genus Gibbula after Calliostoma; but from the nature of the spawn it is more closely related to Patella and probably should hold the first place among the Trochidae, Monodonta following it. A more natural sequence seems to be Trochidae: Gibbula, Monodonta, Margarites, Calliostoma, Cantharidus. The fact that Gersch (1936) has found that Gibbula tumida lays egg masses intermediate between the free eggs and those in gelatinous ribbons or masses shows that it should be placed probably between Monodonta and Margarites. The genera are, however, here left in the order in which they appear in Winckworth's list. 


\section{Genus Margarites}

Margarites helicinus (Fab.).

Jeffreys (I867, III, p. 297) states that the spawn is deposited on seaweed and the under sides of stones. Each egg is enclosed in a yellow membranous capsule, the capsules agglutinated together at the sides to form an irregular "glairy" mass. Thorson (I935, p. 62, figs. 69, 70) has found the egg masses (almost certainly of this species) in East Greenland, and describes them and the young stages. The egg masses are small slimy lumps, each containing about I00-200 irregularly arranged eggs, attached to Laminaria or Fucus fronds. From the lump there emerge several slimy strings which help to fasten the egg masses to the substratum. The eggs are yellowish white. The veliger stage is passed within the capsule and the young emerge in the crawling stage with a shell of one and a fourth whorls (basal diameter ca. $0.25 \mathrm{~mm}$.).

Margarites groenlandicus (Gmelin).

Thorson (1935, p. 63, fig. 70) assumes that this species lays similar egg masses to those of $M$. helicinus, and has a direct development. The embryonic whorls are exactly similar to those of that species and they are difficult to separate in the young stages.

\section{Genus Calliostoma}

The eggs in both the species in which they are known are laid in long gelatinous ribbons, attached more or less firmly, usually by one end, to some substratum, and partly floating. The young are hatched in the crawling stage.

Calliostoma zizyphinum (L.) (Fig. 2a).

Robert (I902, p. 286) describes the spawn and young of Trochus conuloides, subgenus Zizyphinum (= Calliostoma zizyphinum) and figures thenewly hatched larva. Lebour (I936, p. 547, pl. i, figs. I-5) describes the eggs and young. The egg ribbon is many times longer than broad containing hundreds of eggs, attached by one end and floating. The egg is about $0.28 \mathrm{~mm}$. across the egg covering when newly laid. In the newly hatched young there are about one and a half whorls, deeply pitted with large polygonal areas; longitudinal striations following even before hatching. The diameter of newly hatched shells is $0.32 \mathrm{~mm}$. Jeffreys (I867, III, p. 332) describes the "fry" as slightly umbilicate with the topmost whorls reticulate. The breeding season is in spring and summer.

Calliostoma papillosum (da Costa).

This is the Trochus granulatus Born of Jeffreys. Robert (I902, p. 285), who saw the eggs laid, states that this species spawns at Roscoff throughout the year. The spawn is like that of C. zizyphinum, floating and attached loosely at three points. The eggs are yellow and numerous, $0.17 \mathrm{~mm}$. across, and 
irregularly arranged, resembling those of C. zizyphinum. Jeffreys (I867, III, p. 329) states that the first whorl is smooth, the second regularly and strongly cancellated, with a conspicuous umbilicus.

\section{Genus Gibbula}

The eggs are shed singly into the water, hatching as trochophores and attaining a shell before settling down. Gibbula tumida, which is shown by Gersch (1936) to lay its eggs in irregular gelatinous masses, should probably be placed in another genus.

Gibbula eggs are common in the Plymouth plankton, especially in autumn and spring, and although free-swimming for so short a time must be important on account of their numbers.

\section{Gibbula magus (L.).}

Robert (I902, p. 288) describes eggs and young from Roscoff. The eggs are yellowish, $0.12 \mathrm{~mm}$. across, with a gelatinous covering much swollen in the water. The young hatch in about 20 hours as trochophores. The shell appears in a few hours, and is at first simple, then spiral. In I 50 hours tentacles, eyes and epipodial tentacles were present. Jeffreys (III, p. 307) describes the very young shells as being equally convex on each side of the peripheral keel and with the umbilicus very small.

Gibbula tumida (Montagu).

Jeffreys (III, p. 309) states that the "fry" are often marked with spiral pink lines. Gersch (1936) describes and figures the spawn, which is laid in irregular gelatinous masses, much simpler than those of Calliostoma, the gelatinous material probably corresponding to the external coating in that genus. The eggs are $140 \mu$ across. Judging from the form of the spawn this species, as suggested above, should probably be placed in a different genus.

Gibbula cineraria (L.).

Robert (1902, p. 288) states that this species breeds at Roscoff in June. Eggs like those of G. magus, developing and hatching in the same way. At Plymouth ripe eggs may be found in the females in almost any month. Jeffreys (III, p. 3I2) states that the "fry" are not angulated at the base.

Gibbula umbilicalis (da Costa) (Fig. I $l$ ).

Robert (1902, pp. 6, I7), who refers to the species as G. obliquatus, states that the eggs are similar to those of $G$. magus and G. cineraria. Eggs taken from a female at Plymouth were $0.2 \mathrm{~mm}$. across the egg covering, the egg itself being about $0.15 \mathrm{~mm}$. across. The species breeds near Plymouth throughout the year, but especially in winter. Jeffreys (III, p. 315) describes the "fry" as white, nearly flat, with only two or three permanent ribs. A young shell from Plymouth with only a few whorls was beautifully marked with thick rose-pink 
longitudinal lines and was conspicuously striated spirally. Judging from the embryonic whorls of this specimen the free-swimming young must be exceedingly small.

\section{Genus Cantharidus}

The eggs are laid in small gelatinous masses attached by the whole of one surface. The young are hatched in the crawling stage.

\section{Subgenus Jujubinus \\ Cantharidus exasperatus (Pennant).}

Robert (I902, p. 288) describes the spawn as being like that of C. striatus (as Trochus, subgenus Zizyphinus), breeding at Roscoff in spring and summer. The eggs are laid in chaplet form in an ovoid gelatinous mass, flat and fixed by one surface; they are uncoloured. The egg is $0.16 \mathrm{~mm}$. across, like that of Calliostoma zizyphinum. The young go through the veliger stage within the egg covering and hatch in the crawling stage. Jeffreys (III, p. 325) states that the "fry" can be distinguished from those of striatus and exhibit the same relative characters as the adult.

Cantharidus striatus (L.).

Robert (I902, p. 230) made a special study of this species (as Trochus, subgenus Zizyphinus). It lays its eggs in gelatinous oval masses on weeds and stones in large quantities, 20-40 $\mathrm{mm}$. long and I. $15 \mathrm{~mm}$. broad, solidly fixed by one of its large surfaces. The eggs are in the form of a chaplet, whitish and disposed in a flattened spiral. The egg is $0.16 \mathrm{~mm}$. across, much like that of $C$. exasperatus, and hatches in the crawling stage. The veliger is complete in 22 hours. The young are hatched in I 24 hours, having already epipodial tentacles. The species breeds almost throughout the year at Banyuls and Roscoff.

Cantharidus montagui (W. Wood).

Jeffreys (III, p. 322) states that the spiral ridges of the "fry" are frequently marked with reddish lines.

\section{Cantharidus clelondi (Wood).}

\section{Subgenus Clelondella}

This species is the Trochus (zizyphinus) milligranus of Jeffreys who states (III, p. 326) that the "fry" has an umbilical perforation.

\section{Genus Monodonta}

\section{Subgenus Osilinus}

Monodonta lineata (da Costa) (Fig. I $k$ ).

Robert (I902, p. 294) states that the absence of a special gland suggests that the egg laying is similar to that of Gibbula. This is borne out in specimens from 
Plymouth in which ripe eggs, found in March and April, were very like those of Gibbula. Placed in sea water the eggs have a wide spherical gelatinous covering outside the egg covering. The egg is $0.16 \mathrm{~mm}$. across, and the gelatinous covering $0.29 \mathrm{~mm}$. across.

\section{Genus Skenea}

Skenea serpuloides (Montagu).

Jeffreys (III, p. 29I, as Cyclostrema) states that this species deposits its spawn in thick irregular clusters on some of the finer and more membranous seaweeds. Each cluster contains a great number of "fry", having their shells completely formed and enveloped in a "glairy" mass.

\section{Family TURBINIDAE}

\section{Genus Tricolia}

Tricolia pullus (da Costa) (Fig. I $m$ ).

This species was referred to Phasianella by Jeffreys, who describes the "fry" as globular and distinctly umbilicate and states that they might be mistaken for a Lacuna. Specimens in a bowl at Plymouth laid eggs singly into the water like Gibbula. The egg is $0.14 \mathrm{~mm}$. across.

\section{Order MESOGASTROPODA}

The eggs are contained in capsules or gelatinous masses occurring singly or in numbers. Very occasionally the animal is viviparous. The larva hatches as a veliger, as the veliger stage is passed within the egg covering and the young emerge in the crawling stage. In the free-swimming forms the velum is bilobed (Fig. $4 f$ ) or faintly four-lobed. Later it may be four-lobed or six-lobed (Fig. $4 g, h)$. The veligers may remain for a long time in the plankton and the shell may have as many as eight whorls before metamorphosis. Some of the most important planktonic forms belong to this order.

\section{Family LACUNIDAE}

The species may be viviparous, or may hatch in the crawling stage or as veligers, remaining for a short or long time in the plankton. The velum is bilobed. The egg is surrounded by a membrane, an albuminous layer and an egg covering. There are usually several eggs in a gelatinous mass attached by the whole of one surface to a substratum; or, if planktonic capsules, one or a few eggs, the egg covering surrounded by a sheath. 


\section{Genus Lacuna}

(Fig. 2c)

Jeffreys (III, p. 344) refers to L. puteolus (=parva) certain spawn and young which almost certainly belong to L. vincta, and again (p. 350), quoting Spence Bate, describes the young as hatching in the crawling stage-almost certainly $L$. pallidula. The spawn of the latter species has often been taken for that of Littorina obtusata which it resembles, although smaller and more delicate. Caullery \& Pelseneer (I9IO) figured the spawn of Lacuna pallidula as that of L. divaricata (=vincta). Later, Pelseneer (I9II) describes accurately the spawn of L. pallidula and its early embryology. These two species, L. pallidula and $L$. vincta, are apparently the only species whose spawn and development are known. The first hatches in the crawling stage, the second as a veliger with a fairly long planktonic life. The eggs are in gelatinous masses, several in each mass and scattered irregularly, the surface of the gelatinous mass hardening to a certain degree into a pellicle. The later crawling stage shows the two characteristic processes at the hind end of the foot. Hertling \& Ankel (I927) and Hertling (I928) describe the spawn and newly hatched young of both L. pallidula and L. vincta. It is probable that at least one other British species of Lacuna has free-swimming veligers and spawn resembling that of L. vincta, since very similar egg masses of a different species have been observed at Plymouth between tide marks.

Lacuna vincta (Montagu) $=L$. divaricata Fab. (Figs. $2 c ; 4 e$ ).

The spawn of this species is well known and is usually regarded as typical of the genus. The adult is one of the commonest molluscs living between tide marks and below in shallow water, laying its familiar spawn rings on various weeds, brown, green and red. Meyer \& Möbius (1872) describe the egg masses figuring them somewhat inadequately. Delsman (I9I4) gives a good description. All these workers quote Zostera as the substratum on which the eggs are laid. Hertling \& Ankel (I927) found it chiefly on Laminaria and Fucus serratus. At Plymouth it occurs on all these and many others.

The newly laid spawn is in the form of a ring, very slightly spiral, covered with a thin lens-shaped pellicle (Fig. 2c). Sometimes this is somewhat oval in outline. The egg masses enlarge considerably as the larvae develop, reaching sometimes $9 \mathrm{~mm}$. across. Hertling \& Ankel give good figures. The number of eggs is significant-up to I000-1200-while they are much fewer in Lacuna pallidula. Hertling has made important researches into the influence of various chemical and physical factors on the development of Lacuna and Littorina (chiefly Lacuna vincta (=divaricata)).

My own researches on $L$. vincta at Plymouth agree well with those of Hertling. The spawn is found from January to early summer and is usually of a creamy yellow colour (other egg masses which are pink or green almost certainly belong to another species). Spawn was laid in the Laboratory from 
January to May and was always cream-coloured. Eggs laid on January 22 hatched on February 6 as free-swimming veligers with bilobed velum. The average size of the newly laid egg mass is $3 \mathrm{~mm}$. across, increasing as development proceeds. The egg is surrounded by a membrane, an albuminous layer and an egg covering, and is about $0.18 \mathrm{~mm}$. across. On hatching (Fig. 4e) the eyes, otocysts, foot, operculum and velum are all well formed and the mouth open. The shell has about one and a half whorls, clear, colourless and without sculpture. The velum is furnished with long cilia and has a brownish red border. The veligers grow quickly and remain for some time in the plankton, metamorphosing when the shell has about two and a half whorls. The shell of a young $L$. vincta which metamorphosed in the aquarium had three whorls, measured $2 \mathrm{~mm}$. in height, was of a clear horn colour, and had the two long tentacles at the hind end well formed.

Lacuna pallidula (da Costa).

This species lays its eggs in thin gelatinous masses, oval or round, usually on Fucus and Laminaria, often with those of Littorina littoralis (=obtusata), which it closely resembles, although much smaller and with thinner walls. Good figures and descriptions are given by Hertling \& Ankel (1927). The length of the spawn masses is $3.9-5.3 \mathrm{~mm}$., and the breadth $3.3-4.5 \mathrm{~mm}$. The number of eggs is IIO-I25 (Pelseneer), 60-I40 (Hertling \& Ankel). The newly laid eggs are 529-571 $\mu$, gradually enlarging as development proceeds. The veliger stage is passed within the egg covering in the spawn mass, and the young emerge in the crawling stage. The species breeds in late winter, early spring and summer.

\section{Genus Littorina}

(Fig. 2d)

The species of this genus differ in outward appearance from Lacuna in the absence of posterior tentacles and of the umbilicus. The young crawling animal is easily identified by the absence of these tentacles. Jeffreys (III, p. 355) states that most of the species are oviparous and deposit their spawn on seaweeds, rocks or stones. As a matter of fact the only British species known to do this is Littorina littoralis (=obtusata). L. saxatilis (=L. rudis) is viviparous, L. littorea and L. neritoides have planktonic egg capsules from which hatch free-swimming veligers. Again in this genus we find as usual that the more the eggs are protected the fewer the number. L. saxatilis sends out a brood of about 37 young, L. littoralis with no free-swimming stage lays about I 50 eggs, and $L$. littorea about 500. Linke (1933 $a$ ) gives excellent descriptions of the eggs and their origin in all three species. Hertling \& Ankel (1927) had previously supplied much information as to the egg masses of L. littoralis, whilst Delsman (I9I4) had worked out thoroughly the embryology of that species. 
Littorina littorea (L.) (Fig. 2d).

The common periwinkle abounds on all our coasts. The errors of early workers in attributing the spawn of L. littoralis to this species are frequent and are carefully investigated by Hertling \& Ankel (1927). Caullery \& Pelseneer (I9IO) and Tattersall (I9IO) discovered the true nature of the spawn almost simultaneously and showed that $L$. littorea sends out planktonic spawn cases, each containing one to five eggs (very rarely, according to Linke, as many as nine). From these eggs free-swimming veligers hatch which remain in the plankton for some time and can be distinguished by certain characters. I have also observed this species laying egg capsules at Plymouth and both capsules and veligers are common in the coastal plankton. I have figured the eggs and larvae (Lebour, I935 b, figs. 7-9).

The capsule is shaped like a British infantryman's shrapnel helmet (Fig. 2d), and there may be 500 of these laid by one individual. It sinks slowly, those with one egg the slowest of all (Linke), and this is of distinct advantage to the mollusc in keeping in the surface layers for the purposes of distribution, and, when the eggs are hatched, for feeding. The capsule measures about I mm. across, or less, each individual egg measuring about $205 \mu$. The egg develops into a veliger with a well-formed velum and spiral shell of about one and a half whorls, and at this stage the larva breaks through the coverings and hatches. Pelseneer (I9II) gives a partial description of the early larva and the development of the egg. The shell is faintly striated spirally and is of a yellowish colour; the velum has long cilia round its border and is marked with a conspicuous and very characteristic dark purple patch on each lobe. The tentacles, eyes, otocysts, foot and operculum are all well formed. The larva remains for some time in the plankton, metamorphosing when it has about two whorls or rather more. Just before this it can either crawl or swim, and when crawling and the velum is withdrawn the purple pigment shows through the shell as two conspicuous hemispherical patches. Late larvae with brownish shells are common in the plankton near the coast, especially in spring. The species breeds at Plymouth from November to May, chiefly in February and March (Moore, I937).

\section{Subgenus Littorivaga}

\section{Littorina saxatilis (Olivi) (=L. rudis).}

This species of many varieties has long been known to be viviparous, breeding throughout the year. It lives from well above high-water mark to extreme low water and has a wide distribution. The eggs are protected within the body of the parent in a brood sac at the lower end of the oviduct until the crawling stage and are few in number, 28 to 37 according to Linke (I935). Linke describes the genital apparatus and eggs. Delsman (I9I4) has also described the unsegmented eggs which resemble those of L. littorea and L. littoralis with a thin yolk, albuminous layer and the egg covering. Sometimes two or three embryos are in the same covering, rarely four. When ready 
to hatch the young break the covering with their radulae and emerge from the parent as small brown-shelled young with no velum.

Littorina neritoides (L.).

\section{Subgenus Melarhaphe}

The spawn of this species, which for some time was believed to be viviparous, has only lately been recognized. It is now known that it lays planktonic egg capsules, somewhat similar to those of L. littorea but much smaller and each containing only one egg. Dr Otto Linke (1935), of Leipzig, was the first to discover these capsules in specimens sent from Rovigno. Spawn and larvae are also described by Lebour (I935 b, p. 373, figs. I-5, IO, II). It is very surprising to find planktonic egg capsules in a species with such a restricted range and usually living well above the high-tide level. At Plymouth, however, it is sometimes found in small rock cavities in water. The capsules are lensshaped, rounded in the centre of each surface, more curved on one side than on the other, and 0.16 mm. across. Each capsule contains one egg covered with a membrane and floating in a nutritive fluid enclosed in a small circle, the rest of the capsule being outside it. The egg is $0.08 \mathrm{~mm}$. across. The larva hatches as a veliger with a bilobed velum, and the shell has concentric striations with small dots in between.

\section{Subgenus Neritoides}

\section{Littorina littoralis (L.) (=L. obtusata).}

The spawn of this species is laid in kidney-shaped or oval masses on weeds, usually Fucus serratus, on which it lives in large quantities on all our coasts. Frequently the smaller spawn of Lacuna pallidula is seen near it. Delsman (I9I4) has described the embryology, and Hertling \& Ankel (I927) and Linke (1935) have investigated the spawn in detail. It is one of the commonest egg masses but has often been taken for the spawn of other molluscs. Hertling \& Ankel reproduce a very old drawing by Baster (I762) who was the first to describe and figure it. Tattersall (I9IO) and Pelseneer (I9II) both knew it and the latter author figures it. The spawn, which has a slightly yellowish tinge, is transparent and is on an average 7 by $3 \mathrm{~mm}$., enclosing about 90-I50 eggs. The newly hatched egg is about $250 \mu$, surrounded by a thin layer of yolk which apparently soon disappears. The young take three or four weeks to hatch, passing the veliger stage within the gelatinous covering and emerging in the crawling stage, biting their way out with the radula.

\section{Family HYDROBIIDAE}

(Fig. 2e)

The species of this genus either lay eggs in capsules similar to those of typical Rissoidae, or they are viviparous (in fresh water). Only the breeding of Hydrobia ulvae and $H$. ventrosa is known; the first has free-swimming veligers, while the second is viviparous. 


\section{Genus Hydrobia}

Hydrobia ventrosa (Montague) (H. Fenkinsi).

This is a freshwater species, but is frequently found in streams near the sea. It is found with young in all stages inside it in a freshwater stream running down to the sea near Wembury, Plymouth. The species is included here as it is of interest in contrast with the common $H$. ulvae which has sessile egg capsules and a free-swimming veliger.

\section{Hydrobia ulvae Perissant.}

\section{Subgenus Peringia}

This species is very common in estuaries and brackish water districts. Meyer \& Möbius (I872) were the first to record the egg capsules which were laid on neighbouring shells of the same species. Herdman (I888) also records it and Henking (I894) describes the eggs and young, his work being quoted by Simroth (I9II). Specimens from the Plymouth estuaries have laid eggs in captivity, always on one another's shells. The egg capsule is lens-shaped and covered with sand grains, attached to the shell by its flattened base. Inside there may be three to seven eggs. The capsule is about $0.6 \mathrm{~mm}$. across. The egg is covered by a thin membrane, and the eggs are together floating in an albuminous fluid within the capsule. The newly-hatched larva has a horny shell of about one and a half whorls, with tentacles, eyes, otocysts, foot and operculum, and is much like a young Rissoa. The velum is well developed and colourless. The late larva has not been described.

\section{Family RISSOIDAE}

(Fig. 2f)

All the members of this family whose breeding is known lay eggs in capsules, usually lens-shaped and attached by the flattened surface to a substratum. Occasionally they are oval or nearly spherical and attached only partially by one surface. Each capsule usually contains several eggs; the egg is enclosed in a thin membrane and all float together in an albuminous fluid surrounded by the fairly thick-walled capsule. The latter is thinnest in the centre of the free surface where the young break through on hatching. Occasionally the eggs are laid singly in a capsule, or two together, the capsule being oval or round. Where this occurs the young emerge in the crawling stage (Cingula cingillus, C. semicostata), but the larva usually hatches as a veliger with a bilobed velum. The veligers may remain for a short or a long time in the plankton, and typically attain two and a half whorls before metamorphosis, the velum always remaining bilobed.

The Rissoids, both on account of their immense numbers and because most of them stay in the plankton for some time, are of considerable importance. The 
very young herring feed largely on the newly hatched veliger of Rissoa sarsii (Lebour, I934a), and huge numbers of old and young stages of many species are to be seen in the plankton at all times of the year-different species in different seasons. Most of the Rissoids inhabit the region between tide marks and the free-swimming young occur frequently in coastal or shallow-water plankton, but some are deeper water species and have a wide range. Some of the commonest coastal species occurring in the plankton are $R$. parva, almost the whole year round, $R$. sarsii in winter and spring, and, farther out, Alvania punctura in summer and autumn.

Lovén (1839) was the first to describe and figure the veliger of a Rissoid. This he ascribes to Rissoa costata (Alvania crassa), and it has the typical form of a late Rissoid larva, having about two and a half to three whorls and a moderate-sized bilobed velum. It might belong to any typical Rissoid species. This figure is reproduced by Simroth (I9II). Fischer (I892) figures the spawn of Rissoa membranacea, and Pelseneer (I9II) that of $R$. parva. Jeffreys (III, I867) refers briefly to eggs and "fry" of several species, and I have myself described a number of eggs and larvae (Lebour, I934a, 1936). R. octona (L.), not recorded for Britain, is shown by Meyer \& Möbius (I872) to have typical spawn cases. They describe and figure it laid on Zostera and on the shells of its own species, and hatching as a free-swimming veliger.

\section{Genus Cingula}

\section{Subgenus Parvisetia}

Cingula fulgida (J. Adams).

The eggs and young are described and figured by Lebour (1936, p. 548, pl. i, fig. 7). The species is common in rock pools on algae between tide marks and the eggs are laid singly in small tough round capsules on corallines. The capsule is $0.32 \mathrm{~mm}$. across and the egg $0.16 \mathrm{~mm}$. across. As it develops the embryo enlarges considerably and the young hatches in the crawling stage. The newly hatched shell is dark brown with a yellowish operculum. The species breeds in April in the Laboratory.

\section{Subgenus Onoba}

Cingula semicostata (Montagu).

The eggs and larvae are described and figured by Lebour (1934a, p. 536, pl. iii, figs. 19-20). The species is common between tide marks, under stones and among hydroids and algae. Single eggs are laid in tough, oval, thickwalled capsules, usually fixed to small sand grains or mud particles. The capsule is $0.48-0.64 \mathrm{~mm}$. long by $0.32-0.48 \mathrm{~mm}$. broad. The egg in its membrane is $0.24 \mathrm{~mm}$. across when newly laid. The veliger stage is passed within the capsule and the young emerge in the crawling stage. The shell of the newly hatched young is $0.30 \mathrm{~mm}$. across, cream coloured and striated. The species 
breeds from March to May in the Laboratory and young in all stages are found throughout the year.

Cingula semistriata (Montagu).

The eggs and larvae are described and figured by Lebour (1934a, p. 536, pl. iii, figs. I5-I8). The species is common between tide marks on hydroids and algae. The typical sessile lens-shaped capsules are 0.56-0.64 mm. across and $0.24 \mathrm{~mm}$. high, and are colourless and transparent, containing from about I2-22 eggs, $0.08 \mathrm{~mm}$. across when newly laid. The larva hatches as a veliger with a smooth unsculptured shell, about $0.10 \mathrm{~mm}$. across. The animal and velum are colourless. Later veligers have two conspicuous lines below the suture on the body whorl of the shell and three processes at the back of the foot. Breeding in the Laboratory takes place in spring and autumn.

Cingula cingillus (Montagu).

The eggs and larvae are described and figured by Lebour (1936, p. 548, pl. i, figs. 8-IO). They are abundant about high-water mark, sometimes above, on stony and pebbly ground. The eggs are in capsules laid in crevices of stones. The capsules are of typical shape but contain only two to four eggs. They are $0.64-0.72 \mathrm{~mm}$. across, the egg being $0.16 \mathrm{~mm}$. across. The young hatch in the crawling stage with brown shells with about two whorls, and the operculum yellow. The white variety is often found with the typical form; the spawn is similar, the young being colourless with a yellowish operculum. Breeding in the Laboratory takes place in spring.

\section{Genus Alvania}

All species whose young are known have sculptural apices. Certain adult Rissoids from Australia described by Powell (1930) and others mentioned by Thiele (I929) seem to be closely related to Alvania and have similar apices. Thiele places A. cimicoides, which is a British species, in the section Acinulus, subgenus Alvania in the genus Rissoa, and this species has a sculptured apex. $R$. sarsii, with its striated and dotted apex, should probably be placed here, although at present it is left in the genus Rissoa in accordance with Winckworth's classification. All known larvae of this genus remain long in the plankton.

\section{Subgenus Manzonia}

Alvania crassa (Kanmacher).

The eggs are not known, but the larvae have been described and figured by Lebour (I934a, p. 538, pl. iv, figs. 8-IO; I936, p. 549, pl. i, figs. II, I2). It is fairly common in Plymouth Sound, usually below low-water mark. Larvae in all stages are common in the inshore plankton, usually in late summer and autumn. The newly hatched larva is $0.16 \mathrm{~mm}$. across the shell, which has one and a half whorls and is sculptured with spiral lines with irregular divisions; 
the animal and its velum are colourless. Later larvae have beyond the first whorl and a half interrupted striae on the following whorls near the periphery. They metamorphose after having attained about two and a half whorls, when the shell begins to have the adult sculpture.

\section{Subgenus Alvania}

Alvania cimicoides (Forbes).

The embryonic whorls are sculptured (Thiele, I929).

Alvania jeffreysii (Waller).

The apex is blunt and marked with a vandyke pattern instead of having rows of punctures (as in A. punctura; see Jeffreys (IV, I867, p. I5)).

\section{Subgenus Octona}

Alvania punctura (Montague) (=Arsenia punctura).

"The uppermost whorls exhibit under the microscope a few rows of punctures" (Jeffreys, IV, I867, p. I7). The eggs and larvae are described and figured by Lebour (I934a, p. 537, pl. iv, figs. I-7). The species is common at Plymouth below low-water mark and further out among bryozoa. The larvae are common in the plankton in summer and early autumn. The eggs have been seen laid on weeds in the Laboratory. The capsules are of typical form, small and thick-walled, $0.32-0.48 \mathrm{~mm}$. across, rather high, containing about I2-I4 eggs, $0.06 \mathrm{~mm}$. across. The newly hatched larva has a shell of about one and a half whorls, sculptured with spiral striae and dots in between, similar to that of Rissoa sarsii, but smaller. Beyond the first whorl and a half there are small raised spots on the whorls, by which it can be distinguished at once from $R$. sarsii. The animal is yellowish white, and the velum colourless, the shell becoming dark horn colour.

The larval shell when metamorphosis is about to take place is $0.64 \mathrm{~mm}$. long. The larvae remain for a long time in the plankton.

\section{Genus Rissoa}

\section{(Fig. 2f)}

All known species have smooth apices and free-swimming larvae except $R$. sarsii, which has a sculptured apex and should almost certainly be placed in the genus Alvania.

Rissoa albella Lovén.

\section{Subgenus Turboella}

"The spawn cases are generally solitary, semi-globular, membranous and light yellowish brown; the fry emerge from a large hole in the top which appears when they are developed" (Jeffrey, IV, I867, p. 29). 
Rissoa sarsii Lovén.

The eggs and larvae are described and figured by Lebour (I934a, p. 533, pl. i, figs. I, 9-2I (not figs. 2-8); I936, p. 550, pl. i, fig. I3). The adults are not often seen, but they occur between tide marks. The larva is one of the commonest in the winter and spring coastal plankton, forming to a large extent the food of the larval herring in winter. The eggs are in typical lens-shaped capsules $0.48 \mathrm{~mm}$. across, each containing I0-I4 eggs, $0.09 \mathrm{~mm}$. across. The newly hatched larva has a shell $0.12 \mathrm{~mm}$. across, with spiral striae and dots in between. Beyond the first whorl and a half the upper part of the shell is smooth, the periphery and just below having rows of interrupted striae. The shell is colourless and transparent, becoming pale horn colour with a dark brown mouth. The velum is at first colourless, becoming bordered with a fine dark band, occasionally absent on one side. The animal is yellowish with dark brownish purple pigment at the base of the foot in the older larvae which possess the mantle tentacle and a very long posterior tentacle. Metamorphosis takes place when the shell is $0.48 \mathrm{~mm}$. with two and a half to three whorls.

\section{Rissoa inconspicua Alder.}

The egg capsules are described and figured by Meyer \& Möbius (I872) and the free-swimming larvae described. The eggs and larvae are described and figured by Lebour (I934a, p. 533, pl. iv, figs. I3-15). The species is common in shallow water below low-water mark and beyond. The egg capsules are of typical form, $0.48-0.64 \mathrm{~mm}$. across and were laid in the Laboratory on Zostera. There were about six to nine eggs in each capsule. The capsules were laid either on the shell of another individual, or on pieces of debris. The eggs were $0.08 \mathrm{~mm}$. across. The newly hatched larva has a smooth unsculptured shell. The velum is colourless at first, but later bordered with brown. Older larvae have two faint spiral lines round the periphery of the shell. The larvae are common in the plankton, especially in early autumn. The adults breed in captivity in October. Newly metamorphosed animals have the purple apex to the shell characteristic of the adult.

\section{Rissoa parva (da Costa).}

"The spawn capsules are semicircular, yellowish brown and sometimes deposited on the shells of other individuals" (Jeffreys, IV, I867, p. 23). Caullery \& Pelseneer (I9IO) and Pelseneer (I9II), describe the spawn. The eggs and larvae are described and figured by Lebour (I934a, p. 532, pl. iii, figs. I-7). The capsules are $0.64 \mathrm{~mm}$. across or slightly larger, containing 6-50 eggs, $0.09 \mathrm{~mm}$. across. The spawn is usually laid on weeds, both brown and green, in almost any month of the year. The newly hatched larvae have smooth unsculptured shells with one and a half whorls. The velum is colourless; there is a fine line round the periphery of the late larval shell, and dark purple at the base of the foot. The larvae metamorphose when the shell is $0.48 \mathrm{~mm}$. long, with nearly four whorls. This is the commonest of all the Rissoids, 
occurring between tide marks down to extreme low water and sometimes slightly beyond.

Rissoa guerini Récluz.

The eggs and larvae are described by Lebour (I934a, p. 532, pl. iii, figs. 8I4). The species is fairly common among weeds between tide marks. The eggs were laid on weeds in the Laboratory from February to April. The capsules are of typical form, 0.96-I.4 mm. across, containing 80-I00 eggs, $0.09 \mathrm{~mm}$. across. The newly hatched larva has a colourless, smooth and unsculptured shell $0.16 \mathrm{~mm}$. across. The animal is colourless at first, but in a few days the velum becomes spotted with dark brown. The larva metamorphoses when the shell has about three and a half whorls, the foot having a dark patch at the base. The larvae are common in the plankton from spring to autumn.

\section{Subgenus Rissoa}

Rissoa membranacea (J. Adams).

Fischer (I892) briefly describes and figures the egg capsules which are of typical form. The eggs and larvae are described and figured by Lebour (I934 a, p. 529, pl. ii, figs. 6-I 5). This species formerly occurred commonly on Zostera at Plymouth, but it has not been seen for the last few years on account of the disappearance of Zostera from disease. It probably breeds throughout the year. The capsules are $\mathrm{I} \cdot 4-\mathrm{I} \cdot 6 \mathrm{~mm}$. across and contain 40-60 eggs, $0.13 \mathrm{~mm}$. across. The newly hatched young have shells $0.32 \mathrm{~mm}$. across, the animal and velum being colourless. The larva remains only a very short time in the freeswimming stage, metamorphosing when the shell is about $0.37 \mathrm{~mm}$. across and has only two whorls.

\section{Genus Barleeia}

Barleeia unifasciata (Montagu) (=Barleeia rubra).

The eggs and larvae are described and figured by Lebour (I934 $a$, p. 537, pl. iv, figs. II, I2). The species is common on weeds at extreme low tide, locally, usually with Rissoa parva. The egg capsules are round, $0.56 \mathrm{~mm}$. across, and attached to weeds, Fucus and Calliblepharis. There is only one egg, $0.32 \mathrm{~mm}$. across, in each capsule. The larva is hatched in the crawling stage. Adults spawned in the Laboratory in March and April. The newly hatched shell is dark brown with a reddish-brown operculum and one and a half whorls; it is $0.42-0.48 \mathrm{~mm}$. across.

\section{Family TORNIDAE}

\section{Genus Tornus}

Tornus subcarinatus (Montagu).

The eggs are unknown. The larvae are described by Lebour (I936, p. 552, pl. i, figs. I4-I6). They are common in the inshore plankton. The veliger 
remains in the plankton until the shell has about three whorls, the first two being smooth and the third marked with conspicuous raised striae. The shell is $0.48 \mathrm{~mm}$. across when the animal is ready to metamorphose. The velum is bilobed, fairly large, and colourless; the animal is very dark. The late larva shows the typical bilobed pallial tentacle.

\section{Family SKENEOPSIDAE}

\section{Genus Skeneopsis}

Skeneopsis planorbis (Fabricius) (Fig. 2g).

Pelseneer (1926) states that the young hatches in the crawling stage. Linke $\left(1933^{b}\right)$ describes and figures the spawn and the young which confirms Pelseneer's statement. The egg capsules and young have also been obtained in the Plymouth Laboratory. The capsules are round, $0.48 \mathrm{~mm}$. across, and attached to weeds. The young when ready to hatch have brown shells $0.32 \mathrm{~mm}$. across. The species breeds throughout the year. It is very common in rock pools, high up between tide marks.

\section{Family OMALOGYRIDAE}

\section{Genus Omalogyra}

Omalogyra atomus (Philippi) (Fig. 2b).

Jeffreys (IV, I867, p. 7I) states that he found dried up spawn capsules inside the upper cavity of the last whorl, "much larger than the capsules that I have seen in my Rissoa". The species is common in pools high up between tide marks, often with Skeneopsis planorbis. Capsules have been seen in the same position as that described by Jeffreys, but they were much smaller. It is probable that these were the egg capsules, but they have not been hatched out. The young probably hatch in the crawling stage, for very young crawling young with shells only $0.16 \mathrm{~mm}$. across have been seen; it is almost certain that there are no free-swimming stages. The young are found throughout the year.

\section{Family RISSOELLIDAE}

\section{Genus Rissoella}

Rissoella diaphana (Alder).

Jeffreys (IV, I867, p. 60) states that "the spawn deposited by one individual consisted of only two ova, which are enclosed in a hemispherical case". The eggs and young are described and figured by Lebour (1936, p. 552, pl. i, fig. I7). The species is common in the rock pools high up between tide marks. The eggs were laid in the Laboratory in spring and summer. The capsules are hemispherical, thick, colourless, $0.48 \mathrm{~mm}$. long and about $0.25 \mathrm{~mm}$. broad; 
they are attached by a flat base to weed (green or red). Each capsule contains two eggs, about $0.2 \mathrm{~mm}$. across, with egg membrane and albuminous layer, enclosed in an egg covering. The young emerges in the crawling stage, with a shell $0.24 \mathrm{~mm}$. across, of a pale horn colour. The newly hatched animal has two pairs of tentacles and a conspicuous black patch dorsally on the left side. The young in all stages are to be found with the adults in numbers in spring and summer.

\section{Subgenus Jeffreysina}

Rissoella opalina (Jeffreys).

Jeffreys (IV, I867, p. 6I) states that "the spawn deposited on leaves of Laminaria is semi-oval in shape with a large hole in the middle. When ripe it forms a thick mass, and contains an immense number of yellowish unispiral shells which are agglutinated together by a gelatinous matrix."

\section{Family TURRITELLIDAE}

\section{Genus Turritella}

Turritella communis Risso (Fig. $2 h$ ).

The eggs and larvae are described and figured by Lebour (I933d, p. 499, pl. i, figs. I-8). The species is common on muddy ground. Eggs have been laid and hatched in the Laboratory; they are also sometimes found in tow-nettings having been carried up from the bottom mud. The spawn is in grape-like clusters of round gelatinous capsules held together by threads, each capsule being $0 \cdot 64-I \cdot I 2 \mathrm{~mm}$. across, and pale pinkish brown from the pinkish eggs which show through. There are 6-20 eggs or more, $0.10 \mathrm{~mm}$. across, in each capsule; some hundreds of capsules are laid by one individual. The egg has a membrane and floats freely in an albuminous fluid. The newly hatched larval shell has one whorl, smooth and colourless; the animal and the bilobed velum are colourless. It stays only a short time in the plankton. The crawling young have a shell of two and a half whorls and a very broad apex, the last whorl beginning to be ribbed spirally, the ribs being pitted in lines. The spawn is common round Plymouth in summer.

\section{Family CAECIDAE}

\section{Genus Caecum}

Caecum imperforatum (Kanmacher).

Jeffreys (IV, I867, p. 78) states that "the spire of the fry has two whorlsthe inner being sometimes broken off so as to make the centre pervious". The embryonic whorls are cast off in the older individuals, the adult having no spire and the aperture being closed with a shelly flat plate. The eggs are not 
known. The larva is described by Lebour (I936, p. 553, pl. ii, figs. I-5); it is common in the inshore plankton. The veliger has a bilobed velum with a purple border; the shell is a flat spiral and the animal has a yellow digestive gland and is dark purple near the head. It is ready to metamorphose when there are two and a half whorls, and the shell is $0.32 \mathrm{~mm}$. across. Specimens $\mathrm{I} \cdot \mathrm{O} \mathrm{mm}$. in length were found at Plymouth with a coiled spire still present.

\section{Family CERITHIIDAE}

Genus Bittium

Bittium reticulatum (da Costa).

Meyer \& Möbius (1872) have described and figured the spawn as a flat slimy spiral coil, $c a .3 \mathrm{~mm}$. across. Lo Bianco (I888) describes it as a white ribbon irregularly folded on itself and states that they breed from January to May. Free-swimming larvae almost certainly belonging to this species occur commonly in the plankton in spring and summer, usually in shallow water (Lebour, I936, p. 553, pl. ii, fig. 6). The late larva has a pale horn-coloured shell of two and a half whorls, the outer lip being produced as a process as in Cerithiopsis and Triphora though not so pronounced (see below, pp. I37-I38). The velum is colourless and bilobed. The larva metamorphoses when the shell is $0.32 \mathrm{~mm}$. long.

\section{Family CERITHIOPSIDAE}

All the three members of this family known from Plymouth live among sponges, and two of them (the eggs of the third being unknown) lay their eggs in the sponge. The larvae remain for a long time in the plankton, attaining several whorls before metamorphosing. The larval shell is sculptured or smooth, with a shovel-shaped projection of the outer lip to support the velum which is bilobed.

Cerithiopsis tubercularis (Montagu) (Fig. $2 j$ ).

The larvae are described and figured by Lebour (I933c, p. 496, pl. i, figs. 8-II) and later the eggs also (Lebour, I936, p. 544, pl. v, figs. 9-Io). The species is common, living among sponges, chiefly Hymeniacidon, on which it lays its eggs. Holes are made in the sponge and egg capsules, 0.5I mm. across, laid in them. The capsules are full of minute opaque white eggs, $0.06 \mathrm{~mm}$. across. The larvae are common in the plankton, both inshore and offshore, attaining four to four and a half whorls before metamorphosis. The shell is smooth and pale horn colour. The last larval whorl has a large outgrowth from the outer lip bent over the shell mouth; this is marked with concentric striae dotted in between, and replaced at metamorphosis with the reticulated sculpture of the adult. The late larva is $0.64 \mathrm{~mm}$. long. There is a dark line at the suture of the larval whorls and on the columella, and the aperture is 
dark brown. The animal is pale yellowish and the velum colourless, with round and unequal lobes; the foot is mottled with grey on the sole. Breeding takes place in spring and summer.

Cerithiopsis barleei Jeffreys.

The eggs and larvae are described and figured by Lebour (1933c, p. 497, pl. i, figs. I2, I3, pl. ii). The species is common in shallow water on the sponge Ficulina ficus, in which it lays its eggs. The egg capsules are laid in holes in the sponge; they are $1.5 \mathrm{~mm}$. across, and placed at intervals of about $5 \mathrm{~mm}$. or more apart. There are about 200 eggs in each capsule. The newly hatched larval shell is $0.14 \mathrm{~mm}$. across with about one and a quarter whorls; it is light brown, and its surface is covered with raised dots, except at the base, where it is striated. The outer lip is slightly drawn out at first, but later a large shovelshaped process is formed. The velum is colourless with unequal round lobes. The animal is pale yellowish. The third whorl of the shell is ribbed. Late larvae with four and a half whorls are ready to metamorphose. The newly metamorphosed shell is $0.64 \mathrm{~mm}$. long. The larva remains a long time in the plankton. Breeding takes place during spring, summer and autumn.

Cerithiopsis jeffreysi Watson.

This species occurs among sponges at Plymouth, but its eggs and larvae are unknown. Watson (1885) figures the apex of the adult (corresponding with the larval shell) as smooth and having several whorls.

\section{Family TRIPHORIDAE}

\section{Genus Triphora}

The only species of this genus whose eggs are known is Triphora perversa; they were found by Pelseneer (I926). Many pelagic larvae have been recognized. All appear to remain long in the plankton, having many whorls before metamorphosing. Several larval shells of this genus have been ascribed to Sinusigera which is only a larval genus. Vayssière (1930) recently figured Sinusigera dautzenbergi, Craven (1877) Sinusigera perversa (later I884, referred to Triphoris $=$ Triphora) and Boas (I886) Limacina turritelloides; all belong to Triphora. The embryonic whorls are elaborately sculptured.

Triphora perversa (L.).

Pelseneer (I926) described the eggs, laid in a layer on a dead shell of Pectunculus, and figured the newly hatched larvae which were veligers having a sinistral shell and animal. Fischer (I884) states that the larva remains in the plankton until it has eight or nine whorls. The larvae are described by Lebour (I933 c, p. 29I, pl. i, figs. I-7); they are common in the Plymouth plankton both inshore and offshore. Breeding takes place in spring, summer and autumn. The early larva is $0.16 \mathrm{~mm}$. across with a brown sinistral shell covered with 
raised dots, except at the base, where there are spiral striae; the outer lip is produced into a conspicuous process. The animal is pale yellowish white, later having grey on the foot. The velum is colourless with round lobes, becoming unequal. The larva with two whorls has a shell $0.2 \mathrm{~mm}$. long, that with six whorls is $0.64 \mathrm{~mm}$. long. Beyond the first whorl and a half the shell is sculptured with longitudinal striae and keeled, the last whorl before metamorphosis takes place being tuberculated as in the adult. They remain for a long time in the plankton.

\section{Family EPITONIIDAE}

\section{Genus Clathrus}

Clathrus clathrus (L.) (Figs. $3 d, e$ ).

The spawn and newly hatched larvae are described and figured by Vestergaard (I935, p. 22I, figs. 6, 7) who got the adults to lay in an aquarium with sand at the bottom and the young to hatch. The spawn described by her, $3 \mathrm{~cm}$. long, is in a long winding string of triangular capsules, covered with sand grains and containing many eggs. The egg capsules are $2 \mathrm{~mm}$. high. The newly hatched larvae have bilobed vela and smooth shells of about one and a half whorls. The shell of the newly hatched young is $0.15 \mathrm{~mm}$. across. On June Io 1937 some spawn was collected at the Salstone, in the Salcombe Estuary. The parent was found underneath attached by a slimy thread to the egg capsule. Several other similar strings were also found, all lying on mud near green weed. The capsules differed considerably from those described by Vestergaard, for they were covered with fine mud instead of sand and were polygonal and very irregular, only occasionally being triangular. Each mass of spawn covered a space of about $2-2 \frac{1}{2}$ in. The capsules were from 2 to $4 \mathrm{~mm}$. across at the widest part and strung on a gelatinous thread like a necklace (Figs. $3 d, e$ ). It is probable that mud is the natural habitat for this species, and that Vestergaard's aquarium, provided with sand, was unnatural. Her figure shows much more regular triangular capsules than the Salcombe specimens. The eggs, $0.48 \mathrm{~mm}$. across, hatched out on June 24, the veligers corresponding with those described by Vestergaard. Eggs were also obtained in August.

\section{Family IANTHINIDAE}

\section{Genus Ianthina}

\section{Ianthina britannica Forbes \& Hanley.}

This species only rarely occurs off our coasts, mainly on the west and south, but usually only empty shells are seen. The animal secretes from the foot a foamy apparatus formed of air cells which serves as a float. In the female this is used as a raft for the enormous number of eggs which are enclosed in capsules and attached to the under surface from which they hang down 
(Jeffreys, IV, p. 174). Many authors have written about the eggs and raft, some of the most recent being Pelseneer (I9II) and Simroth (I9II). It is figured by Fischer (1887, p. 92) and others.

\section{Family EULIMIDAE}

The larvae belonging to this family remain for some time in the plankton, have smooth shells and a velum with two rounded lobes. The first larva recognized as belonging to Eulima was taken in Norway by Lovén (I844), who identified it as E. distorta (=Balcis devians). It is not certain, however, that this is the right species, as it does not agree with those from Plymouth. Unidentified larvae belonging to the genus Balcis are sometimes found at Plymouth as veligers, besides those described below.

\section{Genus Balcis}

Balcis alba (da Costa) (=Eulima alba) (Fig. 2k).

The eggs and larvae are described by Lebour (I935 a, p. 65, pl. i, figs. I-IO). The adult is commonly dredged off Plymouth. The eggs have been laid in the Laboratory in very thick-walled, oval capsules, 3 by $2.5 \mathrm{~mm}$., colourless and opaque, containing hundreds of pinkish eggs, $0.10 \mathrm{~mm}$. across, enclosed in a membrane and floating in an albuminous fluid. The newly hatched larva has a shell $0.16-0.18 \mathrm{~mm}$. across, with one and a half whorls; it is smooth, colourless and transparent. The apex is very broad. The animal has two conspicuous dark streaks above the mouth; the digestive organs are dark, and the velum bilobed and colourless. The shell has five whorls before metamorphosing and is $0.66-0.72 \mathrm{~mm}$. long. The larva remains a long time in the plankton. It is common inshore and offshore in spring and summer at Plymouth.

\section{Balcis devians (Monterosato) (=Eulima philippi).}

The larvae are described and figured by Lebour (1935 $a$, p. 68, pl. i, figs. III5). They are common in the inshore plankton in spring and summer at Plymouth. They much resemble $B$. alba but have a blunter spine and no black pigment in the animal. The digestive organs are pale yellow. Metamorphosis takes place when there are about four whorls.

\section{Family STYLIFERIDAE}

\section{Genus Pelseneeria}

(Fig. 2l)

Most of the species known live on the tests of echinoderms and lay their eggs in gelatinous masses between the spines (Lamy, I928, p. I80). 


\section{Subgenus Rosenia}

Pelseneeria stylifera (Turton) (Fig. $2 l$ ).

Jeffreys (IV, p. I94) describes the egg masses. The eggs and larvae are described and figured by Lebour (I932 $b$ as Stilifer stylifer, p. II7, pl. i, figs. I-7). The Plymouth specimens were living on Psammechinus miliaris. The eggs are contained in triangular cushion-shaped capsules, colourless and transparent, about I·2 by I.I mm., with a stalk for attachment. Each capsule contains from 60 to 80 eggs, O.I mm. across; they are colourless, with egg membrane, all floating in a fluid in the capsule. The young hatched in the Laboratory had brownish transparent shells of one and a half whorls, about O. I3 mm. across. The velum is bilobed and colourless. The animal is colourless. The shape of the shell closely resembles the newly hatched shell of Balcis alba, with a wide apex.

\section{Family PYRAMIDELLIDAE}

All the members of this family have reversed apices, the planktonic young in their early stages having a sinistral shell and a dextral animal, the shell later also becoming dextral. The early young are thus easy to recognize, at any rate in British waters, where the only truly sinistral planktonic larva is that of Triphora perversa. All the known larvae of the Pyramidellidae are planktonic, the shell being colourless, transparent and smooth. Several have been found at Plymouth, but most of them are not identified as species. Pelseneer (I9II) has described irregular masses of eggs in the foreign parasitic species Angustispira spengeli on Meleagrina and Odostomia tellinae on Tellina. The British species whose spawning is known lay irregular egg masses or lenticular capsules. The egg, with a thin membrane, is enclosed in an egg covering with a very thick layer of albuminous fluid between; it floats in a fluid within the capsule.

\section{Genus Chrysallida}

\section{Subgenus Parthenina}

Chrysallida decussata (Montagu) (= Pyrgulina decussata).

The eggs and larvae are described by Lebour (I936, p. 556, pl. ii, figs. III5). The adult is fairly commonly dredged from the outer grounds near Plymouth. Eggs laid in the Laboratory were in lens-shaped capsules, colourless and transparent, $0.24-0.35 \mathrm{~mm}$. across, and attached by the lower surface to the glass. Each capsule had from four to eight eggs, about $0.09 \mathrm{~mm}$. across. The young when nearly ready to hatch had colourless shells with about one and a half whorls. The animal is colourless, the velum bilobed. It is sometimes found in the plankton after metamorphosis with two to two and a half whorls, beginning to be sculptured and becoming dextral. 
Genus Odostomia

\section{Subgenus Brachystomia}

Odostomia eulimoides Hanley.

The eggs and young are described by Lebour (I932 b, p. II8, pl. i, figs. 9I6). The eggs are common on Chlamys opercularis and, more rarely, on Pecten maximus, being laid in irregular gelatinous masses about $\mathrm{I} \mathrm{mm}$. across on the ears and valves. These masses are clear and colourless, each containing many colourless eggs, $0.16 \mathrm{~mm}$. across the covering. The newly hatched larvae have transparent colourless shells of one and a half whorls and are $0.16 \mathrm{~mm}$. across. The animal is colourless, and the velum bilobed. It has three and a half whorls before becoming dextral and metamorphosing.

\section{Genus Turbonilla}

\section{Turbonilla elegantissima (Montagu) (Turbonilla lactea).}

The crawling young are described and figured by Lebour (I936, pl. ii, figs. I6-I7). They are $0.25 \mathrm{~mm}$. across and the shell is already dextral; therefore the free-swimming stage, which is probably present, must be very short. The adults are commonly dredged in shallow water in muddy ground with stones.

\section{Subgenus Tragula}

Turbonilla fenestrata (Jeffreys).

Jeffreys (IV, p. I 58) describes the egg capsule as "semiglobular, attached by its round and broad base, membranous and thin. When the fry are developed, they find their way out through an oval hole in the centre of the upper part, which then becomes enlarged from what was at first a narrow slit."

Several different planktonic larvae belonging to the Pyramidellidae are found at Plymouth; they are described and figured by Lebour (I936, p. 557, pl. ii, figs. I8-22). All have a bilobed velum, two to two and a half whorls, and a sinistral shell.

\section{Family TRICHOTROPIDAE}

Trichotropis borealis Brod. \& Sowerb. The breeding of this species is unknown in Britain. Thorson (1935, pp. 50-2, figs. 52, 54) has described and figured the eggs and larvae from East Greenland. The capsules are in clusters of two to four; round and oval in shape, with an irregular exit hole; they are deposited on empty bivalve shells. In all seen the hole was open and probably some larvae had escaped. From two to thirteen embryos were seen in each capsule. The young hatch in the crawling stage and have peculiar conchiolin membranes running in spirals on the whorls which are worn off in most of the adults. Thorson (pp. 52-4) also describes somewhat similar capsules and larvae in $T$. conica, attached to sabellid tubes. 


\section{Family CAPULIDAE}

\section{Genus Capulus}

Capulus ungaricus (L.) (Fig. $4 d$ ).

Jeffreys (III, p. 27I) states that the eggs are in little capsules under the body of the parent, fixed by a membrane in front of the foot. Lo Bianco (I888, p. 4I6) gives a similar description. Odhner (I9I4) describes the eggs and newly hatched young and figures the latter which has a well-developed bilobed velum.

On May 5 I937 a small specimen of Capulus ungaricus, $4 \mathrm{~mm}$. across, was taken on a shell of Arca (Barbatia) lactea, dredged on Stoke Point Grounds in red stone. Although so small it was guarding its eggs under the shell in front of the foot. The egg mass measured $2.5 \mathrm{~mm}$. across and was full of developing eggs, each egg being about $0.2 \mathrm{~mm}$. across. These hatched on June II, and it was surprising to find that the larvae were provided with an echinospira shell (a description of the echinospira larva will be found on p. 147). As this type of larva with an accessory shell has only been known hitherto in the Lamellariidae and Triviinae it upsets one's ideas considerably for either Capulus has been wrongly classified and should be placed near the Lamellariidae, or we must expect to find echinospira larvae in other groups. Odhner makes no mention of the echinospira and figures the larva without one. As it is very thin and transparent it may have been overlooked.

When newly hatched the echinospira shell is $0.4 \mathrm{~mm}$. across, the true shell inside it being $0.24 \mathrm{~mm}$. The echinospira (Fig. $4 d$ ) is transparent, gelatinous, and almost spherical, much like that of Velutina described below. The surface is covered with minute round spots which appear to be perforations for some secretion, as droplets stand out as though raised up on small hairs. The spots are arranged irregularly but are inclined to be radial. The developing alimentary canal is very dark, the velum colourless and well developed, and slightly indented in the centre of each lobe which projects beyond the echinospira. The larva is a powerful swimmer and lived in a bowl with small flagellates which it ate freely, the stomach and intestine being well developed. Although they lived for more than a fortnight they did not grow perceptibly and soon died.

The presence of the echinospira in Capulus is most interesting and may entail its being placed in the Lamellarioidea of Schindler (see p. I47). Its larva is quite unlike that of Crepidula or Calyptraea, in both of which genera the adults guard their eggs in the same way. Crepidula fornicata has a freeswimming veliger but no echinospira, according to the description; Calyptraea hatches in the crawling stage. 


\section{Family CALYPTRAEIDAE (L.)}

The eggs are described by Audouin \& Milne-Edwards (1832), Lo Bianco (I888) and Fischer (1892), the last worker figuring them. The eggs and larvae are described by Lebour (1936, p. 554, pl. ii, figs. 24, 25). The capsules are triangular, very soft-walled, fixed in a bunch by their narrow ends to a substratum, usually a stone, and covered by the parent with the part of the body in front of the foot. The capsule is transparent and colourless, $3-3.5 \mathrm{~mm}$. long, pointed at the fixed end and broad at the free end. Each contains about I $2-25$ eggs, $0.48 \mathrm{~mm}$. across, with a thin membrane, and floating in the fluid contained by the capsule. The veliger stage is passed within the capsule, the young emerging in the crawling stage. The shell has rather more than one whorl, about $0.64 \mathrm{~mm}$. across; it is whitish, and the animal is colourless or yellowish white.

Lamy (1928) mentions other foreign species of Calyptraea having similar eggs.

\section{Genus Crepidula}

Crepidula fornicata (L.) (Fig. $2 \mathrm{~m}$ ).

The eggs and larvae are described by Conklin (1891, I897), who worked at its embryology. The eggs are contained in somewhat balloon-shaped capsules $3.5 \mathrm{~mm}$. across, united in a branch by their stalks on a common stem fastened to a stone or shell and covered by the parent. They are figured by Ankel $(1935 a)$. The capsules are thin and delicate, and cream in colour; each has about 250 eggs, ca. $0 \cdot 16 \mathrm{~mm}$. across. About 72 capsules are laid by one individual. The eggs have a thin membrane, and float in a fluid within the capsule. The larva hatches as a veliger and remains some time in the plankton; it is figured by Orton (I9I2-I3). The larval shell is spiral; the velum is large and bilobed; there are regular pigment spots on the larva, green, red, brown, or black (Conklin).

\section{Family APORRHAIIDAE}

\section{Genus Aporrhais}

Aporrhais pespelicani (L.) (Fig. 4h).

Jeffreys (IV, p. 250) describes the young shell. The eggs and larvae are described by Lebour (I933d, p. 503, pl. ii, figs. I-IO). The species is common on mud near Plymouth. It breeds in March and through spring and early summer. The eggs were laid in captivity, but the larvae from them probably hatched prematurely as they had no shell and the velum was almost round. The late larvae are common in the plankton. The eggs, $0.24 \mathrm{~mm}$. across, are laid singly, or two or three together, attached to sand grains or small pieces of debris; they have a thin membrane, an albuminous layer and a tough outer covering, and are transparent and yellowish. The larvae from the plankton have 
a four-lobed velum, with long lobes, each with a large brown spot at the corner; the shell is smooth, $0.56 \mathrm{~mm}$. across, with a broad apex. The late larva has a six-lobed velum, each lobe having a large dark spot at the end and a dark brown border. The shell, about $\mathrm{I} \cdot 4 \mathrm{~mm}$. across, has the last whorl beginning to be spirally striated. It can either crawl or swim. At $\mathrm{I} .5 \mathrm{~mm}$. it metamorphoses, and the animal can be recognized as an Aporrhais. It has long tentacles, and a conspicuous proboscis, beginning to be red; the foot is pointed behind, the shell spirally striated. The larva remains long in the plankton.

\section{Family NATICIDAE}

(Fig. 3c)

All the species whose breeding is known lay their eggs in sandy spirals in which the eggs are glued, usually several in a capsule. The eggs in all known species are covered by a thin membrane, albuminous layer and egg covering, all floating in a fluid within the capsule. These sandy spirals were a great puzzle to the old naturalists but their true nature has been known for some time. Jeffreys (IV, p. 2I2) describes the spawn. Pelseneer (I906) describes and figures larvae from the Bay of Biscay which he attributes to this genus; they are figured and referred to by Simroth (I9II) in his Gastropoda in Nordisches Plankton. Thorson describes the eggs and larvae of three species from East Greenland, all of which have sandy egg spirals but hatch in the crawling stage. These include Natica groenlandica which is also a British species but whose spawn and larvae were not known. Odhner (I9I4) describes the spawn and figures the newly hatched veliger of $N$. maculata (or millipunctata). This is not British but closely related to our British species. When still in the egg the larva has a four-lobed velum with long lobes; the foot is strongly developed, and the animal is able both to swim and crawl when taken out of the capsule. In the plankton it is $\mathrm{I} .4 \mathrm{~mm}$. across the velum, the shell being $0.8 \mathrm{~mm}$. Of the two veligers found at Plymouth, one has been attributed to $N$. catena, the other to $N$. poliana, the two common species. The identification is not certain as they have neither been reared from the egg nor brought through to metamorphosis.

\section{Genus Natica}

Natica catena (da Costa).

\section{Subgenus Lunatia}

The spawn of this species is well known and often found at Plymouth in sandy bays where the adults are common below low-water mark. Jeffreys (IV, p. 2I3) describes the spawn and "fry". Ankel (I930) has described the spawn, developing egg and young; some of the eggs in the capsules devour the others (nurse eggs) so that only a few hatch out. Breeding takes place in spring and early summer. The egg coil forms a more or less complete spiral, 
about I30 to $\mathrm{I} 60 \mathrm{~mm}$. long and $30-40 \mathrm{~mm}$. broad, being $70-80 \mathrm{~mm}$. across the spiral. Eggs in the coil are contained in capsules, $2 \mathrm{~mm}$. across, placed regularly one against the other and finally containing I2 to I5 young Natica which hatch out at intervals of 2 or 3 days (Ankel). The eggs are 0.16 mm. across in the egg covering. Hertling (I932) gives a good photograph of the spawn, and Ankel (1930) figures the young larva from the egg which is hatched as a veliger with a bilobed velum.

The planktonic larva, attributed to this species, is described and figured by Lebour (1936, p. 558, pl. ii, figs. 26, 27). It is common in the inshore plankton in spring; late stages about to metamorphose are sometimes found in summer. The veligers are rather like those of Nassarius reticulatus (see below) but are always distinguishable by the absence of a shell siphon (canal), and in the younger stages there is only a very small projection on the outer lip, so conspicuous in Nassarius. The velum is bilobed, not very large, with a thick purple-brown border. The late larvae are $0.48 \mathrm{~mm}$. across the shell with two and a half whorls. Soon after this stage it can both crawl and swim and then metamorphoses.

Natica pallida Brod. and Sowerb. (=N. groenlandica Möller).

Thorson (1935, p. 55) has described the eggs and larvae from East Greenland; the spawn forms flat semicircular sandy masses about $55 \mathrm{~mm}$. wide and I $2-13 \mathrm{~mm}$. broad. As most of those found were imperfect the spawn may form more than one complete ring. I2-28 capsules were found in a mass, each capsule containing one egg, about $2.25 \mathrm{~mm}$., with a large amount of nutritive fluid and no more eggs. They are deposited freely on the sea bottom. The young emerges in the crawling stage; it has a large umbilicus and radial sculpture (Thorson, figs. 60-I).

\section{Natica poliana Chiaje (Fig. 3 c).}

(Natica alderi of Forbes \& Hanley and Natica pulchella of Hertling.)

The species is common at Plymouth both inshore and offshore. Hertling (I932) has described the eggs and newly hatched larvae. There are no nurse eggs. The spawn is frequently found in sand round Plymouth. It is very much flattened, usually forming an incomplete slightly spiral sandy ring, about $25 \mathrm{~mm}$. across and $7.8 \mathrm{~mm}$. wide. The eggs are $0.24 \mathrm{~mm}$. across the covering. The newly hatched larva is described by Hertling; it has a bilobed velum, apparently colourless. Late larvae, which are common in the plankton, are ascribed to this species and figured by Lebour (1936, p. 559, pl. ii, figs. 28, 29); they are $0.8-\mathrm{I} \mathrm{mm}$. across shell. At about I mm. there are three and a half whorls and the larva can swim or crawl and is ready to metamorphose. The velum is at first small and only slightly four-lobed, but it grows out into four very long lobes, each with a dark brown spot at the end. The late larva is very like that of Nassarius incrassata, differing in the same way as is shown for Natica catena. It is a very important member of the plankton. 


\section{Family LAMELLARIIDAE}

(Figs. $4 a-d$ )

Following Winckworth (I932) the families Lamellariidae and Cypraeidae have been retained, but the latest classification by Schindler (1936) which is very important and significant places the genera Erato, Trivia, Lamellaria and Velutina as follows:

\section{Stirps Cypraeacea; Superfamily LAmellarioIdeA \\ Eratoidae $\left\{\begin{array}{l}\text { Eratoinae: Eratoini:-Erato. } \\ \text { Triviinae: Triviini:-Trivia. }\end{array}\right.$ Lamellariidae $\left\{\begin{array}{l}\text { Lamellariinae:-Lamellaria. } \\ \text { Velutininae:-Velutina. }\end{array}\right.$}

He places the true species of Cypraea in the superfamily Cypraeoidea, including Simnia. This, with other anatomical characters, takes into account the echinospira larva present in Lamellaria, Velutina, Erato and Trivia, but not in the true species of Cypraea. Hitherto, only members of the superfamily Lamellarioidea, as given above, were known to have echinospira larvae, but as is shown above (p. I43) in June 1937 it was found that the larvae of Capulus ungaricus, hatched in the Plymouth Laboratory, also possessed an echinospira shell, very similar to that described in Velutina. This interesting discovery may result in the systematic position of Capulus being revised and its being placed in the Lamellarioidea near Velutina, or it may be that other echinospira in other families are still to be discovered.

The essential feature of the echinospira larva is the presence of an accessory larval shell, the so-called echinospira or scaphoconch (Figs. $4 a-d$ ) which acts as a float and surrounds the true embryonic shell. The echinospira is transparent, colourless and very thin, and is of a membranous character without lime but more or less hard. In Lamellaria, Trivia and Erato it is firm and keeps its shape more or less perfectly when the animal is dead, but in Velutina and Capulus it is gelatinous and fairly soft. The British echinospiras have been described and figured recently, except Capulus (the larva of Velutina plicatilis is unknown); six species are described, Trivia (two), Erato (one), Velutina (one), Lamellaria (two), (Lebour, 1936). The echinospiras were at first regarded by the old naturalists as separate genera and were given separate namesCalcarella, Brownia, etc.; these are now obsolete. All are important in the plankton as they are large; they are powerful swimmers and often abundant. Lamellaria perspicua, whose spawn has long been known, bites holes in compound ascidians and lays its eggs therein. Hennedy (1853) ${ }^{\star}$ and Peach (I858) described the spawn and the echinospira larvae hatching from them many years ago. The echinospira in all known species of the Lamellariidae is

* The reference to Hennedy's statement in the Zoologist for 1853 could not be confirmed. 
nautiloid, though scarcely perceptible in Velutina. The velum is large, bilobed or slightly four-lobed, or six-lobed, and in the late larvae very conspicuous. The true shell lies within the echinospira excentrically, the whorls not corresponding. In Lamellaria the mantle grows up round the true shell, enveloping it, the velum disappears, the echinospira shell and operculum are thrown off and the metamorphosed animal crawls, having the appearance of the adult; the change taking place very rapidly. In Velutina the mantle does not cover the shell in the adult and the newly metamorphosed young is not much like the parent.

Thorson (1935, p. 65) finds that Velutina undata from East Greenland has no free-swimming stage but hatches in the crawling stage.

\section{Velutina velutina (Müller).}

Genus Velutina

The larvae are described and figured by Lebour (1935b, p. 166, pl. iii). The eggs are unknown. It is taken rarely off Plymouth in dredgings. The larva has a slightly nautiloid globular gelatinous echinospira covering of a little more than one whorl, usually more or less covered with minute debris; small dots radiate from near the centre, probably being pores from which mucus exudes. It occurs rather rarely in inshore plankton in late spring and summer. The smallest larva seen was $0.96 \mathrm{~mm}$. across the echinospira. The velum is colourless and bilobed; in late stages it is large with a slight dent in the centre of the margin of each lobe, showing a tendency to be four-lobed. The true shell in later larval stages has about three and a half whorls, with longitudinal ridges (four or five) running outwards from about the middle of the second whorl to the aperture where there is a thick lip. The late larva is about $\mathrm{I} \cdot 4-2 \mathrm{~mm}$. across the echinospira. The young metamorphosed animal has a shell $\mathrm{r} \cdot 28 \mathrm{~mm}$. across, with longitudinal ridges still present.

\section{Genus Lamellaria}

(Fig. 4a)

The echinospira larva of Lamellaria is well known and was described and attributed to that genus by Krohn (I855, 1857). Many workers have also described it (Giard, I875; Pelseneer, I9II; Simroth, I9II ; and others). For a description and summary of literature see Lebour $(1935 b)$. The echinospira is nautiloid with a ridged periphery, the ridges appearing as teeth in side view. The true shell is placed excentrically to the echinospira whorls of which there are several in the later stages. The large velum is at first bilobed and fourlobed, then six-lobed. When ready to metamorphose the mantle rises up round the true shell and the velum, operculum and echinospira shell disappear.

Lamellaria perspicua (L.) (Fig. 4a).

The eggs and early larvae are described by Hennedy (I853), Peach (I858), Giard (I875) and Pelseneer (I9II). Lebour (1935b, p. I64, pl. i) described eggs and all stages up to metamorphosis. Ankel (1935b) describes the formation 
of the egg capsules ("kokons") in detail. The parent lays its eggs in compound ascidians (Leptoclinum (=Trididemnum), Polyclinum, etc.), biting round holes in which the eggs are deposited in capsules, round which the ascidian grows. It is common round our coasts between tide marks and sometimes further out in shallow water. The capsules have a transparent lid through which the eggs, with membrane, can be seen floating in a nutritive fluid. The capsule is about $4 \mathrm{~mm}$. across, and contains many eggs, $0.30 \mathrm{~mm}$. across. According to Giard and Pelseneer some of the developing embryos devour the others (nurse eggs). The newly hatched echinospira is $0.35 \mathrm{~mm}$. across. The velum is bilobed and edged with brown spots. The later larvae have a four-lobed velum which later still becomes six-lobed. The velum has many brown and orange spots and these are also irregularly placed on the other parts of the animal, especially the mantle. Larvae in all stages are found in the plankton throughout the year, especially in spring and summer. This echinospira, ca. $2 \mathrm{~mm}$. across at metamorphosis, may be distinguished from the next species by the numerous and fine ridges round the periphery, which in L. latens (?) are fewer and coarser.

\section{(?) Lamellaria latens (Möller).}

A second species of Lamellaria echinospira is common at Plymouth, usually in deeper water which differs from L. perspicua in the number and form of the ridges on the echinospira shell and in the colour of the animal which is lighter with fewer dark spots. Also it metamorphoses when the echinospira is about $3 \mathrm{~mm}$. instead of about $2 \mathrm{~mm}$. across. This occurs fairly commonly in the outside plankton and is attributed to Lamellaria latens, although the identification is not certain. The larvae are described and figured by Lebour (1935b, p. 165, pl. ii).

\section{Family CYPRAEIDAE}

(Figs. $3 a, b ; 4 c, d$ )

Two species of Trivia, T. monacha and T. arctica, are now recognized as British. These and Erato voluta are the only members of the Cypraeidae (as recognized by early workers) known to have an echinospira larvae. Schiller's new classification, in which he places Trivia and Erato in the Lamellarioidea as distinct from the Cypraeoidea, which is much more natural, is given above (p. I47), and it is hoped that this will be adopted universally. Trivia and Erato have a helicoid echinospira shell instead of nautiloid as in Lamellaria, but otherwise the larvae are very similar. Erato can be distinguished from Trivia in having the whorls of the true shell completely separate from those of the echinospira, lying in it excentrically, whilst in Trivia the whorls run concurrently. For this reason in Erato the echinospira shell is shed complete at metamorphosis, but in Trivia the mantle surrounds the echinospira which is absorbed or disappears. In both Erato and Trivia the young metamorphosed 
shell has a thin outer lip and remains in this state for some time before the characteristic thickening takes place.

In Simnia, which is one of the true species of Cypraea (Cypraeoidea of Schilder), the eggs are entirely different, being laid in layers on Eunicella (Fig. 2i) or Alcyonium on which the animal feeds; the larva has no echinospira shell. Macdonald (I859) described and figured a somewhat similar larva belonging to the genus Pedicularia from the South Seas. This is closely related to Ovula and Simnia. Various species of Cypraea proper and its close relatives are known to lay masses of eggs in horny capsules which they guard, the newly hatched larva having no echinospira shell.

\section{Genus Erato}

Erato voluta (Montagu) ( $=$ E. laevis).

The larvae are described and figured by Lebour (1933 $b$, p. 488, pl. i-ii; I935 $b$, p. I68, pl. vi). The adult is fairly common on the outside dredging grounds. The larva is fairly common in offshore plankton in summer. The eggs are unknown. The echinospira shell is globular and markedly helicoid. The youngest larva seen was $0.64 \mathrm{~mm}$. across the echinospira. It is first very like Lamellaria but soon differs in the form. As the larva grows the true shell becomes very excentric. Round the periphery of the echinospira are lines of small dots similar to those described in Capulus and in Velutina, probably for the passage of mucus. The animal is yellowish with a bilobed velum with a narrow brown border. The velum becomes very large and tends to be slightly four-lobed. Metamorphosis takes place when the echinospira is about $2 \mathrm{~mm}$. across; the mantle covers the true shell when still in the echinospira and when the latter is shed. The larva still keeps the velum for a short period.

\section{Genus Trivia}

Trivia monacha (da Costa) (Figs. $3 a, b)$ (T. europea in part in the Plymouth Marine Fauna).

This and the following species were formerly regarded as one under the name of T. europea. Pelseneer (1926), who first discovered the eggs, described the animal biting holes in compound ascidians and laying their eggs in them. $\mathrm{He}$ also described the newly hatched larva, and, in a later paper (1932), the growth of the young shell to the adult stage. The eggs and larvae are described and figured by Lebour (193I $b$, p. 819, pl. i-iv, as T. europea; 1933a, p. 477; I935b, p. I68, pl. iv). The eggs were laid in Diplosoma and Botryllus in the Laboratory. The capsules are flask-shaped, $4.8 \mathrm{~mm}$. across (Figs. $3 a, b$ ), and contain many. eggs each covered by a thin membrane and all floating in a common fluid. The newly hatched veliger has an echinospira shell of about one and a half whorls, $0.35 \mathrm{~mm}$. across. The animal is dark; the velum is bilobed with a slight lateral indentation and dark purplish border. The echinospira is ready to metamorphose when it is $1 \cdot 25 \mathrm{~mm}$. across; it is 
helicoid, and the whorls of the true shell coincide with the echinospira whorls. The velum grows to a large size. When metamorphosis takes place the mantle rises up and covers both echinospira and true shell, the velum disappearing. The dorsal part of the shell is partially exposed for some time. The shell is smooth and opaque white, with a coiled flat apex and very thin outer lip. The growing mantle is yellowish with purple spots and has papillae at the sides. When full grown the shell lip is thickened. The dorsal part of the shell is coloured with three brown masses, each composed of two parts running together. The whole shell surface is ribbed. The adult is common inshore at Plymouth. Breeding takes place in spring and summer. The larva is fairly common in the plankton.

Trivia arctica (Montagu) ( $=$ T. europea in part, in Plymouth fauna) (Figs. $4 b, c)$.

The larvae are described and figured by Lebour (I933a, p. 48I, pl. i; I935 b, p. I68, pl. iv). The adult is common round Plymouth, both inshore with $T$. monacha and offshore. The larvae are fairly common in the plankton in autumn, winter and early spring. Breeding takes place chiefly in winter. This species has probably often been confused with $T$. monacha and recorded as $T$. europea; it has a more northerly distribution. The eggs are not known, but will almost certainly be found to be similar to those of $T$. monacha. The echinospira shell is very like that of $T$. monacha, but the animal is of a much lighter colour. The velum in later stages grows out into four long lobes, bordered by a fine dark line. The smallest larva seen was $0.4 \mathrm{~mm}$. across the echinospira; the largest, ready to metamorphose, was $\mathrm{I} \cdot 6 \mathrm{~mm}$. across.

\section{Genus Simnia}

\section{Simnia patula (Pennant) (Fig. 2i).}

The eggs and larvae are described by Lebour (I932 a, p. I07, fig. I, pls. I-2). The adult is common at Plymouth among Eunicella and Alcyonium, on which it feeds and lays its eggs. Young and old larvae are common in the plankton in spring and summer chiefly offshore. Breeding takes place from February to July. The eggs are laid in flat layers in capsules, each capsule containing many eggs. These are pink at first but take on a brown appearance from the developing young whose shells are dark brown. The capsule is about $3.5 \mathrm{~mm}$. across. The egg is about $0.13 \mathrm{~mm}$. across. The newly hatched larva is $0.14 \mathrm{~mm}$. across the shell, with about one and a half whorls; the shell is sculptured with irregular granules, being later reticulated at the edge of the aperture. The velum is bilobed and colourless; later it has four very long lobes. When nearly ready to metamorphose the shell (about $0.8 \mathrm{~mm}$. across) has three and a half whorls and a distinct siphon, and the animal can both swim and crawl. It metamorphoses when the shell is about $0.96 \mathrm{~mm}$. across, the mouth gradually growing round the shell and enveloping the embryonic whorls. 


\section{Order STENOGLOSSA}

(Figs. $3 f-j$ )

This order contains our largest gastropods, which lay, usually, hard and horny egg capsules; the commonest species, such as Buccinum undatum (Fig. $3 g$ ), were familiar to the oldest naturalists. Pelseneer (I9IO) and others have shown that the hard coverings of these capsules are formed for the main part by glands of the foot, whereas only a few of the Mesogastropoda form them in this way. The eggs are covered by a thin membrane and float in a nutritive layer surrounded by the capsule. The majority of the British Stenoglossa whose developments are known hatch in the crawling stage and are therefore of no importance in the plankton. Some of them, however, have long planktonic stages, such as Nassarius and most of the turrids, and there are some of the most important and conspicuous planktonic veligers. The capsules may be laid singly or in masses, rows or clusters, and they may have an infinite variety of form. No instance is so far known of the eggs being in simple gelatinous masses nor of their being shed singly into the sea.

\section{Family MURICIDAE}

(Figs. $3 h, i$ )

So far as is known the egg capsules may be lens-shaped or vase-shaped and may be attached to a substratum by the whole of one surface or by a stalk; they may be laid singly or in clusters. The capsules usually contain several eggs. In some nurse eggs are present. The young, so far as is known, emerge in the crawling stage.

\section{Genus Trophon \\ Subgenus Trophonopsis}

Trophon muricatus (Montagu).

Jeffreys (IV, p. 3I7) describes and figures the egg capsules. They are also described and figured by Lebour (I936, p. 560, pl. iii, figs. I-4). They are lens-shaped, colourless, transparent and thick-walled and attached by one surface. Each individual lays from two to nine capsules, $2.5 \mathrm{~mm}$. across, containing several eggs, $0.48 \mathrm{~mm}$. across. The young emerge from a thin oval portion at the top of the capsule, spending the veliger stage inside. The animal, with shell $0.64 \mathrm{~mm}$. across and with about one and a half whorls, and still with the velum can be seen in the capsule.

The adult is occasionally dredged off Plymouth. It breeds from February to June. 


\section{Genus Nucella}

Nucella lapillus (L.) (Fig. $3 h$ ).

The species is very common on rocks, laying its eggs in simple vase-shaped capsules attached to the rock ledges side by side in layers. It has been well known from the earliest times. Many workers have described the spawn (see Jeffreys, IV, p. 275). The capsule is $8-9 \mathrm{~mm}$. high and about $2 \mathrm{~mm}$. across, and attached by a wide flat base with a thin stalk supporting a narrow oval vase; it is hard and yellowish, brown or purple, but usually pale yellow; the top narrows and covers over thinly at the point where the young eventually emerge. Some hundreds of eggs float inside in a fluid; about $15-25$ of these hatch out, the remainder being eaten (nurse eggs) by their neighbours. The young remain in the capsule until the crawling stage. The newly hatched young has a smooth whitish yellow shell with about two whorls. The species breeds throughout the year.

Lamy (I928) describes egg capsules of several other forms closely related to Nucella and very similar.

Urosalpinx cinerea (Say).

\section{Genus Urosalpinx}

This species has recently been introduced into British waters, living chiefly on the oyster beds. It is now included in the British fauna, being found in abundance in the Mersey Estuary. The egg capsules are vase-shaped, and laid in clusters on shells or stones; each is attached by a flat base, and has a thickish stalk supporting the vase. The capsule is $8 \mathrm{~mm}$. high, about $4 \mathrm{~mm}$. thick in the widest part, angulated, horny and hard, and yellowish in colour; it contains several eggs, $0.24 \mathrm{~mm}$. across. The young hatch in the crawling stage, and are somewhat purplish. Breeding takes place in summer (information kindly supplied by Prof. J. H. Orton). The capsules are figured and described by Orton (1929).

\section{Genus Ocenebra}

Ocenebra erinacea (L.) (Fig. 3i).

Jeffreys (IV, p. 309) describes the egg capsules. This species is common on our shores on the rocks and under stones between tide marks and beyond. Its eggs are laid in clusters in the rock crevices or on stones and shells and are somewhat similar to those of Nucella but angular, and having much fewer eggs and no nurse eggs. The young emerge in the crawling stage. The capsule is yellowish, about Io mm. high, and hard and horny; it is fixed by a flat base and a narrow stalk supports the vase which is somewhat flattened on one surface and rounded on the other with three keels which make the section triangular. Each capsule contains from I2 to 20 eggs, all of which usually develop. Breeding takes place in late spring and summer. The newly hatched young are $0.96 \mathrm{~mm}$. long, with the beginning of a siphon; the shell is smooth with about two and a half whorls, the edge beginning to be crenulated. 


\section{Family BUCCINIDAE}

(Fig. 3g)

The eggs are laid in horny capsules, either singly or several together, usually attached to some substratum or to one another, and sometimes forming large masses. The capsule is more or less lens-shaped, the opening for the young to emerge being at the side or base. Nurse eggs are often present, and one capsule may contain hundreds of eggs of which only a few hatch. In all instances known the young emerge in the crawling stage with usually several whorls. Thorson (1935) gives descriptions of the eggs and young of several species from East Greenland.

Liomesus ovum (Turton).

Genus Liomesus

Jeffreys (Iv, p. 299) describes and figures the egg cases (as Buccinopsis dalei) as sometimes deposited on the under side of the maternal shell; the base is narrower than the upper portion. This is not the Tritonium ovum of Middendorff (=Buccinum ovum Midd. of Thorson, p. 34).

Beringius turtoni (Bean).

\section{Genus Beringius}

The egg capsules are described by Howse (I847 as Fusus turtoni), and quoted by Jeffreys (IV, p. 332): "Eggs pale orange, either solitary or two together and attached side by side, not to each other, but to a rather broad membranous substratum, they are triangularly oval, the base being the narrowest part and consisting of an outer filmy sheath and an inner and thick fibrous case, the latter resembles in structure a coconut husk, the opening is a wide slit at the top. Six fry in one capsule. Fry almost cylindrical and of a dark reddish brown hue."

\section{Genus Volutopsius}

Volutopsius norwegicus (Gmelin).

The egg capsules are described and figured by Howse (I847, p. I62, pl. x, fig. 3, as Fusus norwegicus). The capsules were first noticed by $\mathrm{Mr}$ King (Jeffreys, IV, p. 33I), solitary, forming a compressed hemisphere, about an inch in diameter, dirty lemon colour, semi-transparent, attached by the whole of its base to the inside of old bivalve shells and other flat substances and edged by a rim or strip of membrane. The upper surface is covered with a thin whitish coat, which breaks up into crystalline particles and is finely corrugated. The underside is satiny. The ova are pink or bright flesh-colour. There are 2 to 4 perfect "fry" in each capsule which escape through a slit in the rim. Thorson (1935, p. 23, fig. I8) shows an almost more than subhemispherical capsule from East Greenland, which is dull, yellowish cream colour, slightly tuberculated and fairly transparent. The base is $28-30 \mathrm{~mm}$. It only contained immature eggs. Friele (I882) and Dons (I9I3) also mention the capsules. 
Colus islandicus (Gmelin).

\section{Genus Colus}

The only British record occurs off the Shetlands. Thorson (I935, p. I3, figs $5-7$ as Sipho) describes the eggs and young, the egg capsules having been previously described by Friele (I882). The capsule is light yellow, lens-shaped, slightly domed, and attached by a flat base to some substratum, usually stones. A medium-sized capsule has a basal diameter of I $3 \mathrm{~mm}$. with 7350 eggs. Only one to five embryos usually develop, the rest being eaten (nurse eggs); once I6 were found, but there were generally three. The smallest capsule had a basal diameter of $1 \cdot 5-1 \cdot 75 \mathrm{~mm}$. The apex is oblique. The largest embryo before emerging is $8.5 \mathrm{~mm}$. (only one embryo in capsule with base $12 \mathrm{~mm}$.) and has three and a half whorls, a little more than half a whorl being spirally sculptured as in the adult. On the occasion when there were 16 embryos in a capsule, I $5 \mathrm{~mm}$. at base, the young emerged with one and a half to two whorls and a length of $3.5 \mathrm{~mm}$. The size of the young depends on the number of nurse eggs per embryo.

Colus gracilis (da Costa).

The egg capsules are described by Jeffreys (Iv, p. 337 as Fusus) "solitary, small, membranous, pouch-shaped and attached by a broad base to stones and corallines: this surface is microscopically and closely reticulated; orifice extremely large, and sometimes having the edge partly stained with pink. Each capsule contains only a single embryonic shell, which is transparent, and through it may be seen the orange liver and two unequal-sized plumes of pale yellow gills."

Colus howsei (Marshall).

Subgenus Siphonorbis

Jeffreys (IV, p. 339 as Fusus propinquus) describes the egg capsules as "solitary and attached to the inside of old bivalves; they are hemispherical, and resemble those of $F$. gracilis, but have a smaller and oval orifice; the base is margined by a narrow membrane. Embryo the colour of a pomegranate."

Colus jeffreysianus (Fischer).

Jeffreys (IV, p. 34I) describes the "fry" (as Fusus buccinatus) as "distinct from that of $F$. propinquus as the adult of each from one another".

Neptunea antiqua (L.).

\section{Genus Neptunea}

Jeffreys (IV, p. 327, pl. iv, fig. 3) describes and figures the spawn (as Fusus antiquus) and states that it has been well described by Baster (I762) in his "Opuscula subseciva". "Egg cases or capsules overlap one another in an imbricated fashion, each being firmly attached by its base to the underlying capsule." They are also described and figured by Meyer and Möbius (I872): 
"They are deposited in clusters of from a dozen to a hundred, the capsules in each cluster being equal in size. Those which compose one cluster, however, are not half as large as those forming another cluster, although in both cases the fry are in the same state of maturity. When they are dry, the upper or convex side shrivels, and is wrinkled and pitted; the under or flat side (which by contraction becomes concave) is of a silky texture, and divided across by a few lines; the opening is a wide slit, lying just under the top which makes a narrow flap. Before leaving the capsule the fry are perfectly formed, with conspicuous tentacles, eyes and operculum. The shell has two whorls, the first being smooth and the others showing a few incipient striae. Each capsule produces only from 2 to 4 fry. The latter end of winter seems to be the spawning season."

\section{Genus Buccinum}

Buccinum undatum (L.) (Fig. $3 g$ ).

Baster (I762) and many other early writers have investigated the spawn. It is figured in Ellis's Corallines as Alcyonium and Vesicularia marina of Bauhm, and by Fischer (1887, p. 92) and among others in the Plymouth Aquarium Guide (1935, p. 39). They are called "sea-wash" balls because they are used by sailors to wash their hands. Dr Johnston compares the egg mass to the nest of a bumble-bee (very appropriate). Jeffreys (IV, p. 29I) describes the spawn: "it is composed of numerous cartilaginous pouches (in reality of chitin), of the shape and size of a large split pea, piled irregularly one upon another, and attached to their edges at the base.....Each cell contains at first several hundred eggs, which are afterwards so greatly reduced in number that only from I5 to 30 fry come to maturity." The spawning season is between October and May according to locality. The young emerge in the crawling stage with about two and a half whorls. The shell is smooth, beginning to be spirally striated on the outer whorl, and the shell siphon is beginning to be formed. The newly hatched young are about I mm. long.

\section{Buccinum humphreysianum Bennett.}

Jeffreys (IV, p. 395) states that the egg cases are separate and hemispherical. Thorson (1935, pp. 24-35) describes the spawn of five species from East Greenland, all being very similar to those of $B$. undatum and all hatching in the crawling stage.

\section{Genus Chauvetia}

Chauvetia brunnea $($ Donovan $)=$ Syntagmabrunnea in Plymouth Marine Fauna.

At Plymouth, spawn cases were found in the plunger jars inhabited by this species, but without eggs. The capsules were similar to those of Philbertia, being lens-shaped, colourless and transparent; they were attached to the glass by the flat under surface, the upper part being rounded with a very thin portion in the centre. 


\section{Family NASSARIIDAE}

(Fig. 3j)

The egg capsules are more or less flattened and horny, flask-shaped or irregularly vase-shaped. They are laid singly, or in rows, or scattered irregularly in masses, attached to some substratum, stones, shells, Bryozoa, Hydrozoa or Algae. No nurse eggs are known, all the eggs in a capsule usually developing. There are many eggs in each capsule, with membranes, and floating together in a fluid within the capsule. The capsule is usually attached to the substratum by a flattened base, a narrower portion bearing the flask, which is inflated, usually narrowing at the top and closed with a thin covering which is broken when the eggs emerge. All the species whose young are known hatch as freeswimming veligers, some remaining for a long time in the plankton.

\section{Genus Nassarius}

\section{Nassarius reticulatus (L.).}

\section{Subgenus Hima}

The egg capsules are described and figured by Jeffreys (IV, p. 348) as Nassa; Pelseneer (I9II) describes the eggs and larvae up to the time of hatching and figures the developing embryos. He also (1906) figures the egg capsule and larval shell. Ankel (1929) has investigated the laying of the egg capsule and gives photographic illustrations. The capsules are well-known objects, often seen in rows on the leaves of Zostera. The eggs and larvae are described and figured by Lebour (I93I $a$, p. 797, fig. I, pl. i, figs. I-2, pl. ii and iii) and the whole life history was followed. The adult is common on our coasts, the larvae being very common in the coastal plankton throughout the year but especially in spring and summer. The capsule is pale horn colour, hard, rounded on one flattened surface and almost flat on the other, vase-shaped, fixed by a flat base, then narrowing and enlarging again into the vase; it is $4.8-5 \mathrm{~mm}$. high, and about $4 \mathrm{~mm}$. across, containing about 50, or less, to I00 eggs, $0.16 \mathrm{~mm}$. across, all of which usually develop. The newly hatched larva is free-swimming, about $0.28-0.30 \mathrm{~mm}$. across the shell with about one and a half whorls. The velum is bilobed with a reddish brown border. The outer lip of the shell projects into a conspicuous process. The late larva has a slight constriction in the velar lobes, making them tend to be four-lobed. When the shell is $0.72-$ $0.8 \mathrm{~mm}$. across with three whorls it metamorphoses, the shell canal having been formed earlier and the animal both swimming and crawling.

Nassarius incrassatus (Ström) (Fig. 3j).

The eggs and larvae are described and figured by Lebour (I93 I $a$, p. 797, figs. 2 and $3, \mathrm{pl}$. iv and v). They are much like those of $N$. reticulata but smaller. The capsules are usually laid in clusters but sometimes a few in a row, on Bryozoa, hydroids or weeds. Fischer (1892) was the first to describe 
the capsules. The capsule is $1 \cdot 5^{-2} \mathrm{~mm}$. high, containing several eggs, $0.16 \mathrm{~mm}$. across. The newly hatched larva has a shell $0.18-0.02 \mathrm{~mm}$. across, with one and a half whorls; the velum is bilobed, at first being colourless, and later having a brown border. In a few days the velum develops four lobes which later grow very long, each with a brown spot at the end. The larvae are ready to metamorphose with a shell $\mathrm{I} .5 \mathrm{~mm}$. high; they can both crawl and swim. The adults are very common on the shore and below low-water mark. The larvae are very common in the inshore plankton and sometimes also in the offshore waters, the late stages being found much farther out than those of N.reticulatus. Breeding takes place chiefly in spring and summer, but occasionally larvae may be found in any month of the year. It is one of the most important planktonic veligers.

Nassarius pygmaeus (Lamarck).

Although this is a British species, its eggs and young have not been seen here. Vestergaard (I935, p. 2I8, figs. I, 3) has described them from Northeast Jutland, occurring at a depth of 20-25 metres, one capsule being on a Delesseria and four on the shell of a living specimen of Aporrhais pespelicani. The capsules were solitary, $2.5 \mathrm{~mm}$. high and $\mathrm{I} .5 \mathrm{~mm}$. broad, thus being slightly larger than those of $N$. incrassatus; they were also similar in shape but rather rounder with a broader base, containing 40-50 eggs which hatched out. The newly hatched larva had a shell $0.2 \mathrm{~mm}$. across with rather more than one whorl and a small process on the outer lip. The velum was bilobed, the lobes being rounded, and bordered with red-brown. A later stage, almost certainly belonging to this species, has a shell about I mm. high, with a radial sculpture; the outer aperture has a tooth-like process as in the other Nassarius larvae; the velum is large and four-lobed.

Egg capsules of other Nassarius species from different countries are described and resemble those of the British species (Tryon, I88I), Nassa obsoleta has much corrugated capsules but similarly shaped (Ankel, I929).

\section{Family TURRIDAE}

(Figs. $3 f ; 4 g$ )

The egg capsules, so far as is known, are lens-shaped, solitary, and attached by the whole of the flattened base to some substratum. In the centre of the free convex surface is the exit hole covered by a thin membrane. The embryonic whorls of the adults which represent the larval shells are sharply differentiated into two groups, those with smooth apices (Haedropleura, Lora, Mangelia) and those with reticulated or elaborately sculptured apices (Philbertia).

In all British species known the larva hatches as a veliger, but Thorson (I935, p. 36) has described and figured from East Greenland the spawn and young of five species of Bela (= Lora of Winckworth) including B. trevelyana Turton=Lora trevelliana Turton of Winckworth, which is also a British 
species. Its spawn and young have not yet been identified in British waters. In all the East Greenland species Thorson found that the young emerged in the crawling stage. The British species whose developments are known have a long veliger stage and are important members of the plankton. Verrill (I882) has observed similarly shaped capsules belonging to several species of Bela from New England. Larvae which are probably Haedroplura septangularis are described and figured by Lebour (I936, p. 562, pl. iii, figs. 8-I8).

Lora turricula (Montagu).

\section{Genus Lora}

Breeding is unknown in British waters, but Vestergaard (I935, p. 218, figs. I, 2) has described the capsules and newly hatched young from Frederikshavn, Denmark (as Bela). The capsule has two ridges running from the centre and dividing its surface into halves. The newly hatched young have a smooth shell and a large velum with large pigment spots not unlike those of Mangelia (see below).

All the species of Bela described by Thorson have similar ridges on the capsule, and the capsule of Philbertia gracilis from Plymouth (see below) are also divided, but in Mangelia nebula and Philbertia linearis these ridges or divisions were not seen.

An unknown turrid larva, probably belonging to the genus Lora, has been described and figured by Lebour (I936, p. 563, pl. iii, figs. I9, 20).

\section{Genus Mangelia}

The only egg capsules known belonging to this genus are those of Mangelia nebula which are very like those of Philbertia, and of Bela described by Thorson but without the ridges. The capsules are quite smooth. The larvae of Mangelia nebula are very striking veligers remaining for a long time in the plankton and having a very large velum decorated with spots in a similar way to that of Lora turricula described by Vestergaard in the young larva; but in the older larva the velum hangs over the shell like a true veil. A second late larva which metamorphosed in captivity is described and figured by Lebour (I936, p. 563, pl. iii, figs. 5-7) which is very similar to that of Mangelia nebula but slightly larger and with very faint striae on the apex. This has been attributed provisionally to $M$. coarctata, the only other species of Mangelia known from Plymouth; although having an operculum in the metamorphosed form the identification is somewhat doubtful.

\section{Mangelia nebula (Montagu).}

\section{Subgenus Bela}

The eggs and larvae are described and figured by Lebour (I934 b, p. 547, pl. ii). The adult is common in Plymouth Sound and sometimes outside in shallow water. The larvae are common in the plankton, both in inshore and 
offshore waters. The egg capsules are lens-shaped, smooth and transparent, $\mathrm{I} \cdot 6 \mathrm{~mm}$. across, containing about 60 eggs, $0.16 \mathrm{~mm}$. across. Even before the larva leaves the egg the velum is large and ornamented with conspicuous orange spots. The shell of the newly hatched larva is smooth and $0.23 \mathrm{~mm}$. across; the velum is bilobed. Later larvae have a very large velum which may completely cover the shell, and the last whorl of the shell begins to be tuberculated; the siphon is conspicuous. The shell is $0.96-\mathrm{I} \mathrm{mm}$. long with three and a half to four whorls when ready to metamorphose. The base of the foot is pale grey, otherwise the animal is colourless. Breeding takes place in summer.

\section{Genus Philbertia}

(Figs. $3 f ; 4 g$ )

So far as is known the larvae of this genus closely resemble one another, the shells being conspicuously sculptured and attaining a large size before losing the velum which is bilobed or four-lobed and usually large. The capsules are of the usual turrid form, with or without ridges.

\section{Subgenus Comarmondia}

Philbertia gracilis (Montagu).

The eggs and larvae are described and figured by Lebour (I933 c, p. 507, pl. i, I 9346 , p. 550, pl. iv, fig. 6). The adult is dredged fairly commonly usually outside Plymouth Sound. Larvae are fairly common in the plankton in spring and summer. The capsules are $3.4 \mathrm{~mm}$. across with ridges dividing them across on the surface; they are coarsely reticulated and contain about $40-80$ eggs, $0.16 \mathrm{~mm}$. across. The young remain long in the capsule and before hatching have a large slightly bilobed velum with heavy brown pigment and the shell siphon already formed. The newly hatched larval shell is $0.24^{-}$ $0.80 \mathrm{~mm}$. long, the size varying with the number of eggs in the capsule, as was found by Thorson (1935) in many of the East Greenland prosobranchs. One capsule contained 40 young, $0.80 \mathrm{~mm}$. long. The shell aperture is drawn out externally into a process; the velum at first slightly four-lobed with a large amount of brown pigment, later develops very long lobes (Fig. $4 g$ ). The shell is dark brown, heavily sculptured with irregular dots and flecks on the first two to two and a half whorls, the later whorls keeled with oblique striations. There are large orange and brown spots on the velar lobes. The animal is yellowish and can swim or crawl when the shell is $\mathrm{I} \cdot 76 \mathrm{~mm}$. long with four and a half whorls and then it metamorphoses. It is important in the plankton.

\section{Subgenus Philbertia}

From the apices of all the species known which are sculptured in a characteristic way it can be seen that the larval shell has several whorls before metamorphosis and that the shell is always reticulated, the first one and a half 
whorls with straight reticulations, which in the later whorls are oblique. It is the same with the subgenus Teres and probably with many others of the genus, but the sculpture is quite different from that of Comarmondia and the apices sharply differentiated from Mangelia and Lora. The velum in all those known is colourless and bilobed to four-lobed, the lobes rounded and not large. Jeffreys (IV, p. 366) has noted the sculpture of several species, and this characteristic sculpture is well known to palaeontologists and systematists generally.

\section{Philbertia leufroyi (Smith).}

Jeffreys (IV, p. 366) notes the apex (as Defrancia). The eggs are not known. The larvae are described and figured by Lebour (I934 b, p. 553, pl. iv, figs. I, 2, $4,8)$. They are very like those of $P$. linearis (see below) but with fewer whorls and broader; the velum is rather larger; the animal is very similar, having three and a half whorls in the embryonic shell and being pinkish brown to deeper brown. It is not uncommon in the plankton in spring and summer. The late veliger has a shell $0.70-0.80 \mathrm{~mm}$. high.

Philbertia purpurea (Montagu).

Jeffreys (IV, p. 273) notes the sculpture and embryonic whorls (as Defrancia), also Lebour $(\mathrm{I} 934 b)$ notes three whorls.

\section{Philbertia asperrima (Brown).}

Jeffreys (IV, p. 37I) notes the sculpture of the embryonic shell (as Defrancia reticulata). The late larvae are described together with the embryonic whorls by Lebour (I934b). The larva is very similar to that of Philbertia linearis, the embryonic shell having four and a half whorls with very irregular reticulations, and being of a lighter colour.

\section{Philbertia linearis (Montagu).}

Jeffreys (IV, p. 369) (as Defrancia) has described the egg capsules and newly hatched young, and also the sculpture of the embryonic whorls. His measurements of the capsules do not agree with those from Plymouth and may refer to a different species. The eggs and larvae are described by Lebour (I934b, p. 550, pl. iii, figs. I-6, pl. iv, figs. 3, 5, 7). The adult is fairly common in dredgings from the Sound and occasionally outside. The larvae are common in the inshore and offshore plankton in spring and summer, rarely in autumn. Capsules were laid in the Laboratory in February and March; they were $\mathrm{I} .5 \mathrm{~mm}$. to $2 \mathrm{~mm}$. across, without ridges, and containing 60-80 eggs, $0 . \mathrm{I}_{4}-$ $0.15 \mathrm{~mm}$. across. The larvae did not hatch out, but all stages are to be found in the plankton. There is a dark reticulated shell. The velum is colourless, bilobed at first, later developing four-lobes; the lobes are round and short. The youngest larva seen was $0.19 \mathrm{~mm}$. across with one and a half whorls; the outer lip was produced. In the late larva the shell is $0.80 \mathrm{~mm}$. long with four whorls, when it is ready to metamorphose. 
Philbertia teres (Reeve).

\section{Subgenus Teres}

Jeffreys (IV, p. 262) notes the sculpture of the embryonic whorls (as Defrancia), as does also Lebour (1934b, pl. iii, figs. 8-20). The late larva has four whorls.

\section{REFERENCES}

Adams, A., I857. A new species of Macgillivrayia. Ann. Mag. Nat. Hist., Ser. 2, Vol. xIx, pp. 373-4.

- I86I. On a supposed new genus and on some new species of pelagic Mollusca. Ann. Mag. Nat. Hist., Ser. 3, Vol. viII, pp. 40I-4.

ANKel, W. E., 1929. Über die Bildung der Eikapsel bei Nassa-Arten. Zool. Anz. Supp. 4 (Verh. d. Deutsch. Gesellsch. E. V. auf der 33. Fahresversammlung zu Marburg), pp. 219-30.

— 1930. Nähreierbildung bei Natica catena (da Costa). Zool. Anz., Bd. 89, pp. I29-35.

I935a. Die Pantoffelschnecke, ein Schädling der Auster. Natur und Volk, Vol. 65, pp. 173-6.

— I935b. Das Gelege von Lamellaria perspicua L. Zeitschr. Morphol. Ökologie Tiere, Bd. 30, Heft 4, pp. 635-47.

BASTER, J., I762-65. Naturkundige Uitspanningen. Te Haarlem by J. Bosch.

BOAS, J. E. V., I886. Bidrag til Pteropodernes Morfologi og Systematik samt til Kundskaben om deres geografiske Udbredelse. Spolia Atlantica. Kgl. Dansk. Vid. Selsk. Skr. (6), Vol. Iv, No. I, 23I pp.

Lo Bianco, S., I888. Notizie biologiche riguardante specialmente il periodo di maturità sessuale degli animali del golfo di Napoli. Mitt. Zool. Stat. Neapel, Vol. viII, pp. 385-440.

- I899. Notizie biologiche riguardante specialmente il periodo di maturità sessuale degli animali del golfo di Napoli. Mitt. Zool. Stat. Neapel, Vol. xIII, pp. 448-573.

Boutan, L., I885. Recherches sur l'Anatomie et le Développement de la Fissurelle. Arch. Zool. Exp. Gén., 2 e Sér., T. III bis. Suppl., 4 e Mém. pp. I-I73.

- 1898. Sur le développement de l'Acmaea virginea. C.R. Acad. Sci. Paris, CXXvi, pp. 1887-9.

— I899. La cause principale de l'asymétrie des mollusques gastéropodes. Arch.

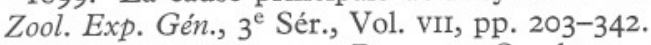

Caullery, M. \& Pelseneer, P., igio. Sur la ponte et le développement du Vignot (Littorina littorea). Bull. Sci. France Belgique, T. XLIV, pp. 357-60.

Conklin, E. G., I891. Preliminary Note on the Embryology of Crepidula fornicata and of Urosalpinx cinerea. Fohns Hopkins University Circulars, Vol. 10, No. 88, pp. $89-90$.

I897. The embryology of Crepidula. A contribution to the cell lineage and early development of some marine gastropods. Fourn. Morph., Vol. xIII, No. I, pp. I-226.

Cooke, A. H., I895. Molluscs. In the Cambridge Natural History, III, pp. I-459.

Crofts, D. R., I929. Haliotis. L.M.B.C. Memoirs, xxix, pp. I-I74.

Craven, A. E., I877. Monographie du genre Sinusigera. Ann. Soc. Malac. Belgique, Vol. xII, p. II2.

_ I883. On the Genus Sinusigera d'Orb. Ann. Mag. Nat. Hist., Ser. 5, Vol. xI, pp. I4I-2.

Davis, J. R. Ainsworth \& Fleure, H. J., 1903. Patella. L.M.B.C. Memoirs, x, pp. $\mathrm{I}-76$. 
Delsman, H. C., I9I4. Entwicklungsgeschichte von Littorina obtusata. Tijdschr. Nederl. Dierkundige Vereeniging, Ser. 2, Deel I3, pp. I70-340.

Dons, C., I9I3. Om eggloegningen hos enkelte Buccinider Zoologiske notiser. II. Tromsø Museums Aarshefter, 35-36.

Fischer, H., I892. Recherches sur la Morphologie du Foie des Gastéropodes. Bull. Sci. France Belgique, xxIv (4), Vol. III, pp. 260-346.

Fischer, P., I880-87. Manuel de Conchyliologie.

Flattely, F. W. \& Walton, C. L., I922. The Biology of the Sea-Shore. Pp. I-334. London.

FrIele, H., I882. The Norwegian North-Atlantic Expedition, 1876-78. Mollusca, I-2 (pt. I, pp. 38; pt. 2, pp. 44).

GersCH, M., I936. Der Genitalapparat und die Sexualbiologie der Nordseetrochiden. Zeitsch. Morph. Ökologie Tiere, Bd. 31, Heft I, pp. I06-50.

Giard, A., I875. Sur l'Embryologie du Lamellaria perspicua. C.R. Acad. Sci. Paris, T. Lxxx, pp. 736-9.

- I885-6. Synopsis de la Faune Marine de la France Septentrionale (Suite I). Bull. Sci. Département du Nord, No. 5-6 (1886), pp. 157-78.

Henking, H., I894. Beiträge zur Kenntnis von Hydrobia ulvae Penn. und deren Brutpflege. Ber. naturf. Ges. zu Freiburg i. B. viII, pp. 89-I Io.

Herdman, W., I888-9. Note in Second Annual Report of the Liverpool Marine Biological Station on Puffin Island. Proc. Liv. Biol. Soc. III, I888-9.

HertLING, H., I928. Beobachtung und Versuche an den Eiern von Littorina und Lacuna. Bedeutung der Eihüllen. Wiss. Meeres. Komm. Unt. deutsch. Meere, N.F., Abt. Helgoland, Bd. xvir, 2, 49 pp.

- 1932. Zur Kenntnis des Laichbandes und der Veligerlarven von Natica pulchella Risso. Zool. Anz., Bd. 100, pp. 95-100.

Hertling, H. \& ANkel, W. E., I927. Bemerkungen über Laich und Jugendformen von Littorina und Lacuna. Wiss. Meeres. Komm. Unt. deutsch. Meere, N.F., Abt. Helgoland, Bd. xvi, 7, I3 pp.

Howse, R., I847. Notes on a Dredging Excursion off the Coast of Durham, with Descriptions of the Ova-capsules of Fusus norvegicus and F. turtoni. Ann. Mag. Nat. Hist., Vol. xIx, pp. I60-4.

Jefrereys, J. G., I863-9. British Conchology, Vol. II, I863; Vol. III, I865; Vol. IV, I867; Vol. v, 1869 .

KROHN, A., I853. Úber einen neuen, mit Wimpersegeln versehenen Gasteropoden. Arch. Naturgesch. xIx. Jahrg. pp. 223-5.

— 1855. Nachtrag zu dem Aufsatze über die Echinospira diaphana. Arch. Naturgesch. xxi. Jahrg. pp. I-5.

I857. Fernere Nachträge zu dem Aufsatze über Echinospira nebst Beobachtungen über eine ihr verwandte Larve. Arch. Naturgesch. xxirr. Jahrg. pp. 252$6 \mathrm{r}$.

Lamy, E., I928. La Ponte chez les Gastéropodes prosobranches. Fourn. Conchyliologie, Vol. LXXII, pp. 25-52, 80-I26.

Lebour, M. V., I93Ia. The larval stages of Nassarius reticulatus and Nassarius incrassatus. Fourn. Mar. Biol. Assoc., Vol. xvil, No. 3, pp. 797-818.

— I93I b. The larval stages of Trivia europea. Fourn. Mar. Biol. Assoc., Vol. xvIr, No. 3, pp. 819-32.

_ 1932 a. The larval stages of Simnia patula. Fourn. Mar. Biol. Assoc., Vol. xvirI, No. I, May, pp. I07-I5.

- I932b. The eggs and early larval stages of two commensal gastropods, Stilifer stylifer and Odostomia eulimoides. Fourn. Mar. Biol. Assoc., Vol. xviII, pp. I I7-22. I933a. The British species of Trivia: T. arctica and T. monacha. Fourn. Mar. Biol. Assoc., Vol. xvin, No. 2, Jan., pp. 477-84. 
Lebour, M. V., I933b. The larval stages of Erato voluta (Montagu). Fourn. Mar. Biol. Assoc., Vol. xvirI, No. 2, pp. 485-90.

- I933c. The life-histories of Cerithiopsis tubercularis (Montagu), C. barleei Jeffreys and Triphora perversa (L.). Fourn. Mar. Biol. Assoc., Vol. xviII, No. 2, pp. $49 \mathrm{I}-8$.

I 1933 d. The eggs and larvae of Turritella communis Lamarck and Aporrhais pespelicani (L.). Fourn. Mar. Biol. Assoc., Vol. xvin, No. 2, pp. 499-506.

I 1933 e. The eggs and larvae of Philbertia gracilis (Montagu). Fourn. Mar. Biol. Assoc., Vol. xviII, No. 2, pp. 507-IO.

- I933f. The importance of larval Mollusca in the plankton. Fourn. Cons. Int. Expl. Mer, Vol. viII, No. 3, pp. 335-43.

I $1934 a$. Rissoid larvae as food of the young herring. The eggs and larvae of the Plymouth Rissoidae. Fourn. Mar. Biol. Assoc., Vol. xIx, No. 2, May, pp. 523-39.

- I934b. The eggs and larvae of some British Turridae. Fourn. Mar. Biol. Assoc., Vol. xix, No. 2, May, pp. 54I-554.

I 1935 a. The echinospira larvae of Plymouth. Proc. Zool. Soc. London, pp. I63-74. I935b. The breeding of Littorina neritoides. Fourn. Mar. Biol. Assoc., Vol. xx, No. 2, Aug., pp. 373-8.

- 1936. Notes on the eggs and larvae of some Plymouth prosobranchs. Fourn. Mar. Biol. Assoc., Vol. xx, No. 3, pp. 547-65.

Linke, O., I933a. Morphologie und Physiologie des Genitalsapparates der Nordseelittorinen. Wiss. Meeres. Komm. Unt. deutsch. Meere in Kiel und der Biol. Anst. Helgoland, N.F., Helgoland, Bd. xIx, 5, 60 pp.

- 1933b. Der Laich von Skeneopsis planorbis O. Fabricius (Gastrop. Prosobranch.). Zool. Anz., Bd. I03, Heft II/12, pp. 207-II.

- 1935. Der Laich von Littorina (Melaraphe) neritoides (L.). Zool. Anz., Bd. II2, Heft 3/4, pp. 57-62.

LovÉN, H., I839. Bidrag till Känmadomen af Molluskernas utveckling. Kongl. Vetenskaps-Akademien Handlingar Stockholm för år I839, pp. 227-4I.

- I844. Om Nordiska Hafs-Mollusken. Ofversight af Kongl. Vetenskaps-Akademien Förhandlingar Stockholm första ărgăngen, pp. 48-53.

Lund, A., I834. Recherches sur les enveloppes d'œufs des Mollusques gastéropodes pectinibranches. Ann. Sci. Nat., S. 2, Zool., T. I, pp. 84-II2.

MAcBride, E. W., I9I4. Text-book of Embryology, Vol. I, Mollusca, pp. 29I-37I.

Macdonald, J., I855. Note in Ann. Mag. Nat. Hist., Ser. 2, Vol. xvi, pp. 206-7 (Proc. of Learned Societies, April 26).

Macdonald, J. D., I859. On the probable metamorphosis of Pedicularia and other forms. Trans. Linn. Soc. London, Vol. xxII, pp. 24I-3.

1860. Further observations on the metamorphosis of Gasteropoda. Trans. Linn. Soc. London, Vol. xxiII, pt. I, pp. 69-82.

Meyer, H. A. \& MöвIUS, K., I872. Fauna der Kieler Bucht, Bd. 2, Die Prosobranchia und Lamellibranchia, pp. i-xxiv, I-I39.

Milne-Edwards, H., I832. In Audouin \& Milne-Edwards. Recherches Hist. Nat. litt. France.

Moore, H. B., I937. The biology of Littorina littorea. Part I. Growth of the shell and tissues, spawning, length of life and mortality. Fourn. Mar. Biol. Assoc., Vol. xxI, No. 2, pp. $721-42$.

Moorhouse, F. W., I932. Notes on Trochus niloticus. Great Barrier Reef Expedition, 1928-29. Scientific Reports, Vol. III, No. 5, British Museum (Natural History), pp. $145-55$.

ODHNER, N. H., I9I4. Notizen über die Fauna der Adria bei Rovigno. Beiträge zur Kenntnis der marinen Molluskenfauna von Rovigno in Istrien. Zool. Anz., Bd. 44, pp. I56-70. 
Orton, J. H., I9I2-I3. An American enemy of the English oyster farmer. Trans. Plymouth Institution, pp. 247-6r.

- I928. Observations on Patella vulgata. Part I. Sex phenomena, breeding and shell-growth. Fourn. Mar. Biol. Assoc., Vol. xv, No. 3, pp. 85I-74.

Orton, J. H. \& Amirthalingam, C., I929. The oyster drills on English oyster beds. Nature, Vol. cxxiv, Aug. 24, pp. 298-9.

Patten, W., I886. The embryology of Patella. Arb. Zool. Inst. Wien, Bd. vi, pp. I4974.

PEACH, C. W., I858. A few remarks on Lamellaria tentaculata and its nidification, etc., as observed at Wick. Proc. Roy. Phys. Soc. Edinburgh, Vol .r, pp. 455-8.

Pelseneer, P., I894. Introduction à l'étude des Mollusques, pp. I-217. Bruxelles.

- 1906. Mollusca in A Treatise on Zoology, edited by E. Ray Lankester, Part v, pp. I-355.

- I9I0. Glandes pédieuses et coques ovigères des Gastropodes. Bull. Sci. France Belgique, T. XLIv, pp. I-9.

- I9II. Recherches sur l'embryologie des Gastropodes. Mém. Acad. Royale Belgique, $2^{\mathrm{e}}$ Sér., T. III, pp. I-I67.

— I926. Notes d'Embryologie malacologique. Ponte et développement de Cypraea europea, Triforis perversa et Lucina lactea. Bull. Biol. France Belgique, T. LX, pp. 88-II2.

— I932. La métamorphose préadulte des Cypraeidae. Bull. Biol. France Belgique, T. LXVI, 2, pp. I49-63.

Powell, A. W. B., I930. New species of New Zealand Mollusca from shallow-water dredgings. Trans. and Proc. N.Z. Inst., Vol. 60, Part 4, pp. 532-43.

Robert, A., I902. Recherches sur le Développement des Troques. Arch. Zool. Exp. Gén., $3^{\text {e }}$ Sér., x, pp. 269-538.

ScHILDER, F. A., I936. Anatomical characters of the Cypraeacea which confirm the conchological classification. Proc. Malacol. Soc., Vol. xxII, Part II, pp. 75-II2.

Simroth, H., I895. Die Gastropoden der Plankton-Expedition. Erg. d. Plank. Exp. der Humboldt-Stiftung, Bd. II, F.d. pp. I-206.

— I896-I907. Mollusca in Bronn's Tierreich, Bd. III, Abt. II, Gastropoda Prosobranchia, pp. 628-720.

- I9II. Die Gastropoden des Nordischen Planktons. Nordisches Plankton, v, pp. $\mathrm{I}-36$.

Smith, F. G. W., 1935. The Development of Patella vulgata. Phil. Trans. R. Soc. London, Ser. B, Biol. Sci. No. 520, Vol. 225, pp. 95-125.

Stephenson, T. A., I924. Notes on Haliotis tuberculata. Fourn. Mar. Biol. Assoc., Vol. xIII, No. 2, pp. 480-95.

Tattersali, W. M., I908. British Association Reports, Dublin, p. 746; Nature, Vol. 78, Oct. 22, 1908, p. 649.

- I910. Athenaeum, Feb. I3, pp. 203-4, and at the Challenger Society, Jan. I9Io, 1920. Notes on the breeding habits and life-history of the periwinkle. Fisheries. Ireland. Sci. Inv. I920, No. I, pp. I-I I.

ThIELE, J., I929. Handbuch der systematischer Weichtierkunde, Teil. I-2, pp. I-778.

Thorson, G., I935. Studies of the egg capsules and development of Arctic marine prosobranchs. Medd. om Grønland, Bd. Ioo, Nr. 5, pp. I-7I.

TrYon, G. W., I88r. Manual of Conchology, 3ro pp.

VAYSSIÈRE, A., I923. Recherches zoologiques et anatomiques sur les Mollusques de la famille des Cypraeidés. I ${ }^{\text {ère }}$ Partie. Ann. Mus. Hist. Nat. Marseille, Zool., T. XVIII, pp. I-I2O.

— I930. Etude zoologique et anatomique sur quelques gastéropodes Prosobranches provenant des Campagnes Scientifiques du Prince Albert $\mathrm{I}^{\text {er }}$ de Monaco. Rés. Camp. Sci. Albert I Ir, Fasc. Lxxx, I930, pp. I-26. 
VerriLl, A. E., I882. Catalogue of Marine Mollusca, added to the Fauna of New England during ten years. Part I. Trans. Connect. Acad. Sci. and Arts v, pp. 447586.

VestergaARD, K., I935. Über den Laich und die Larven von Scalaria communis (Lam.), Nassarius pygmaeus (Lam.) und Bela turricola (Mont.). Zool. Anz., Bd. I09, Heft 7/8, pp. 217-22.

Watson, R. B., I885. On the Cerithiopsides from the eastern side of the North Atlantic. Fourn. Linn. Soc., Vol. xxix, pp. 89-95.

Wegmann, H., I884. Contribution à l'Histoire Naturelle des Haliotides. Arch. Zool.

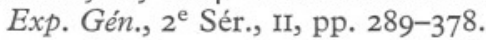

Willcox, M. A., I905. Biology of Acmaea testudinalis Müll. American Naturalist, Vol. xxxix, pp. 325-33.

WILsON, E. B., I904. Experimental studies in germinal localization. (I) The germ region in the egg of Dentalium. (2) Experiments on the cleavage-mosaic in Patella and Dentalium. Fourn. Exp. Zool., Vol. I, pp. 197-268.

Winckworth, R., I932. The British marine Mollusca. Fourn. Conch., Vol. I9, No. 7 , pp. $21 \mathrm{I}-52$.

1934. Names of British Mollusca. II. Fourn. Conch., Vol. 20, No. I, pp. 9-15.

Note. Miss D. R. Crofts' monograph “The Development of Haliotis tuberculata, with special reference to Organogenesis during Torsion" (Phil. Trans. Roy. Soc. London, Ser. B, Biol. Sci., No. 552, Vol. 228, Oct. I937) arrived too late to be included in the present work. 